\title{
The Role of Economic Complexity in the Ecological Footprint: A Review of the EKC Hypothesis for Iran
}

\author{
Ali Moridian ${ }^{1} \quad$ alimoridian@ymail.com \\ Nasser Yarmohammadian² \\ Masoumeh Motalebi ${ }^{3}$ \\ Afsaneh Shadmehr ${ }^{4}$
}

Received: 27/04/2021 | Accepted: 10/07/2021

\begin{abstract}
The aim of this study is to test the validity of the Kuznets Environmental Curve (EKC) hypothesis for Iran. For this purpose, this study used the FourierARDL method and causality test with time change to analyze the short-term and long-term relationships between economic growth, economic complexity index, energy consumption, and ecological footprint. Findings from the Fourier ARDL approach confirm the existence of coherence between variables. In addition, the results of this study show that energy consumption and economic growth increase the ecological footprint in the short and long term. However, the short-term elasticity of economic growth is smaller than the long-term elasticity, meaning that the EKC hypothesis is not valid for Iran. This finding is confirmed by causality test with time change. The overall results show that economic complexity has a diminishing effect on the ecological footprint and economic growth is not effective in solving environmental problems in Iran. Therefore, the Iranian government should encourage an environmentally friendly production process and cleaner technologies in exports to reduce environmental pollution.
\end{abstract}

Keywords: Economic Complexity, Fourier ARDL, Casualty Test with Time Change, Ecological Footprint, Environment.

JEL Classification: Q53, C32, O33.

1. M.A. in Urban and Regional Economics, Isfahan University of Arts, Isfahan, Iran (Correspondence Author).

2. Assistant Professor, Department of Urban Economics, Isfahan University of Arts, Isfahan, Iran.

3. Ph.D. of Public Sector Economics, Lorestan University, Khorramabad, Iran.

4. M.A. in Economics, Islamic Azad University, Science and Research Branch, Tehran, Iran. 


\section{نقش بيجيدكى اقتصادى در ردياى بومشناختى:

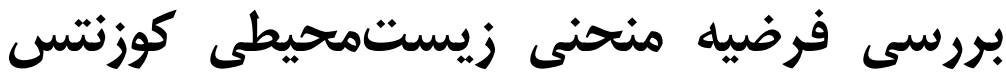 (EKC)}

alimoridian@ymail.com

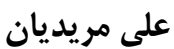
كارشناس ارشد اقتصاد شهرى ومنطقاى، دانشخاه هنر اصفهان، ايران (نويسنده مسئول). ناصر يارمحمديان استاديار كروهاقتصاد شهرى، دانشكاه هنر اصفهان، ايران.

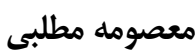
دكترى اقتصاد بخش عمومى، دانشكاه لرستان خرمآباد، ايران. افسانه شادمهر كارشناسارشد اقتصاد، دانشكاه آزاد اسلامى، واحد علوم و تحقيقات، تهران، ايران.

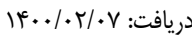

جكيده: يزوهش حاضر با هدف آزمون اعتبار فرضيه منحنى زيستمحيطى كوزنتس إنس

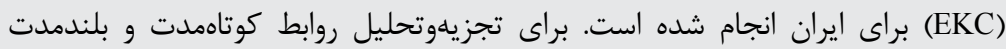

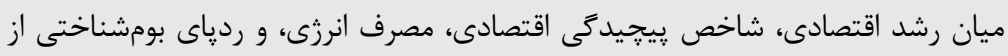

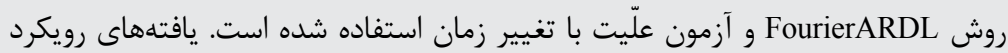
FourierARDL

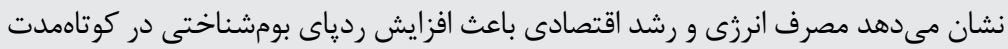

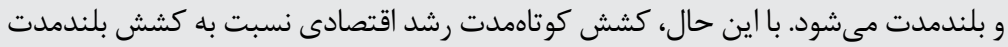

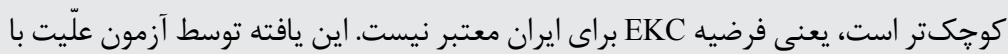

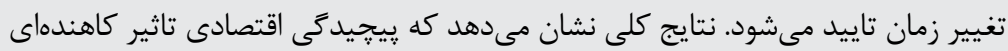

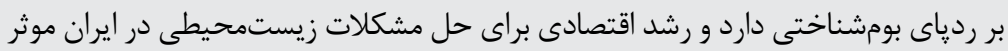

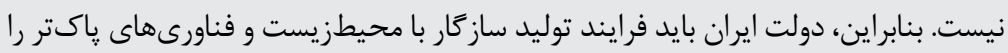

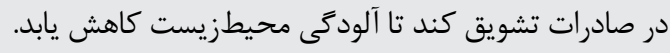

كليدوازهها: پِيجيدگى اقتصادى، بوتاسترب FARDL، علّيت متغير با زمان، ردياى بومشناختى، محيطزيست. طبقدبندى Q53, C32, O33: 


\section{مقلم}

از زمان انقلاب صنعتى، فناورىهاى جديد با تاكيد بر نقش ساختارهاى اقتصادى كشورها در افزايش

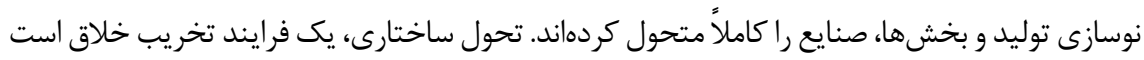

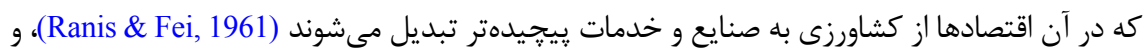
بلهور مستقيم بر محيط اثر مى گذارند. براى مثال، مى توان به رشد سريع مصرف سوخت فسيلى فيلى و انتشار

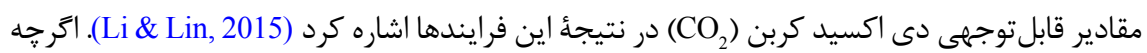
برجستهسازى اثرهاى مثبت و منفى بر بخشهاى خاص آسان است، اما تجزيهوتحليل و اندازهيرى ردياى كلى محيطزيست از تخصيص مجدد فعاليتها در كل اقتصاد بسيار دشوارتر است. از يك طرف، تحول در ساختار توليدى و روند صنعتى شدن باعث افزايش مصرف انرزى و انتشار

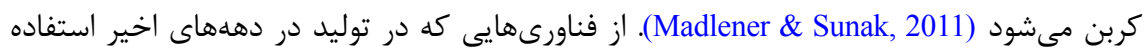
مىشود، تاثيرات زيستمحيطى بسيار بيشترى نسبت به فناورىهاى قديمى بر جاى مى گذارد. براى نمونه، در بخش كشاورزى، كودهاى شيميايى جايكزين سيستم كوددهى سنتى در مزارع شده

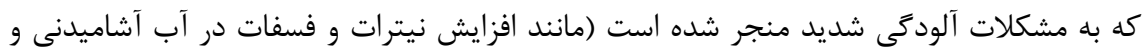

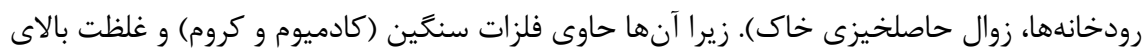

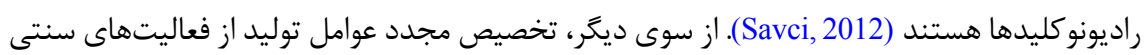
به فعاليتهاى مدرن نيز مىتواند با ايجاد روشهاى جديد در كاهش آلودگى و توليد انرزى پاكتر (صفحات خورشيدى، توربين هاى بادى، برق) اثرات مثبتى داشته باشد. فناورىهاى سبز و نوآورى مهاى

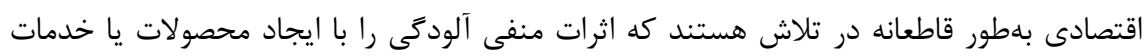

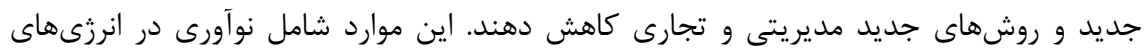

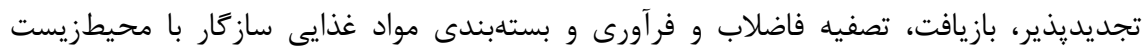
مىشود. بازار جهانى محصولات و خدمات زيستمحيطى در حال رشد است و سياستخذاران اكنون توجه بيشترى به صنعت كالا و خدمات زيستمحيطى (EGS)' دارند كه به عنوان ماده اصلى رقابت صنعتى، مزيت تجارى و ثبات اجتماعى تلقى مىشود (Sinclair-Desgagné, 2008).

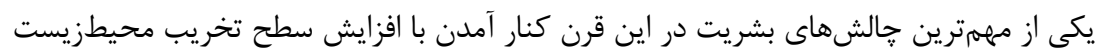

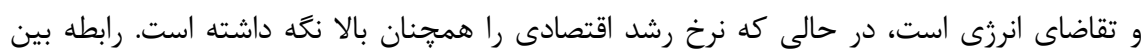

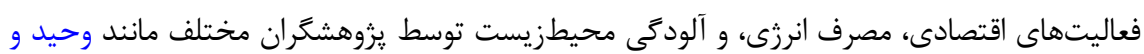




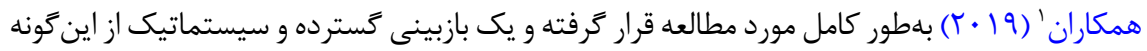

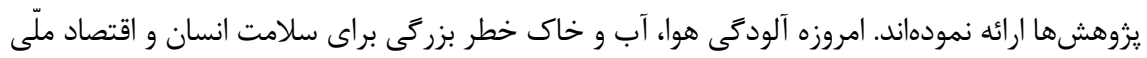
است. با وجود بهبود سطح كارايى، افزايش سطح آلودگى به دليل تقاضاى انسانى براى منابع طبيعى آنى

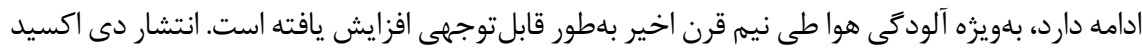
كربن (CO

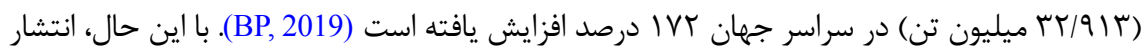

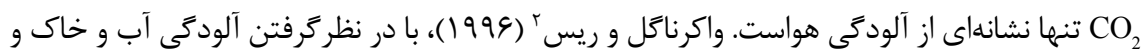

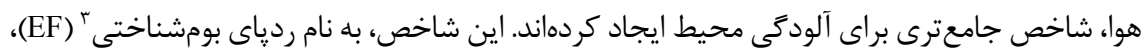

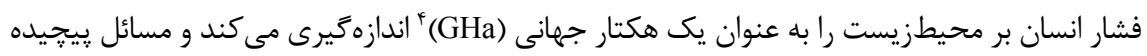
زيستمحيطى را منعكس مىنمايد (Wang et al., 2018). به عنوان يك شاخص فشرده براى فشار زيستمحيطى، اثر زيستمحيطى (EF) بيانكر مقدار كل منابع طبيعى است كه يك جمعيت مصرف مى كند (Bagliani et al., 2008) و مساحت زمين و و آب توليدى لازم را براى حمايت از فعاليتهاى انسانى و توزيع زبالههاى توليدشده اندازه مى ميرد

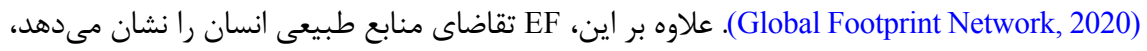
در حالى كه ظرفيت زيستى منبع منابع طبيعى است. با مقايسه EF با ظرفيت زيستى، مىتوان منطقة

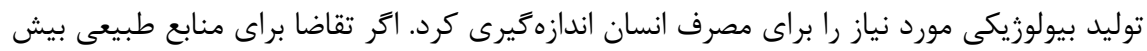

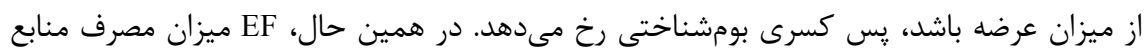
انسانى را نشان مى دهد كه بيش از محدوديتهاى زيستمحيطى است (Yilanci \& Pata, 2020b). براى اولين بار، EF جهان در سال • ا9 الاتر از ظرفيت بيولوزيكى بود، يعنى مردم فراتر از ظرفيت

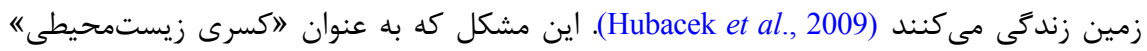

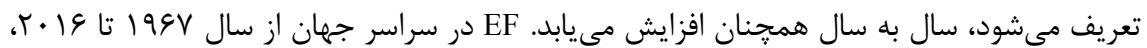

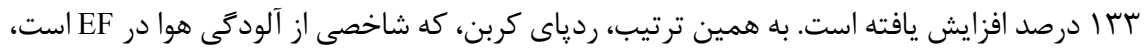
در همان مدت 191 درصد افزايش يافته است (Global Footprint Network, 2020). هنگًامى كه هم انتشار CO $\mathrm{CO}_{2}$ و هرسى معىشود، بديهى است كه شرايط محيطى در سراسر جهان در حال بدتر

1. Waheed et al.

2. Wackernagel \& Rees 
شدن است. بنابراين، تعيين عوامل موثر بر آلودگى محيطزيست و در نتيجه انجام اقدامات مختلف براى آيندهُ بهتر ضرورى است. ادبيات اخير با بررسى عوامل تعيينكننده (براى مثال صنايع، جهانىسازى، كشاورزى، توسعه مالى، مصرف انرزى، سرمايهگذارى، تجارت، شهرنشينى، و سرمايه انسانى) در دورههاى زمانى مختلف براى

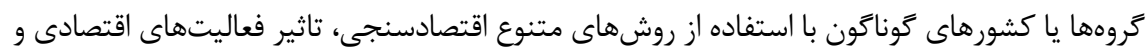
اجتماعى را بر ردياى اكولوزيكى نشان داده است (Destek et al., 2018; Charfeddine, 2017). رشد اقتصادى يك كشور با ساختار خاصى از اقتصاد پايدار است و نياز به يك ساختار مصرف

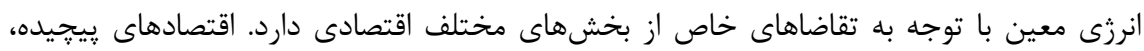

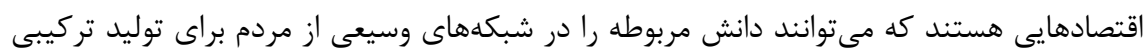
متنوع از محصولات پييجيده مديريت كنند. يِيجيدگى اقتصادى به ساختار توليدى يك كشور اشاره

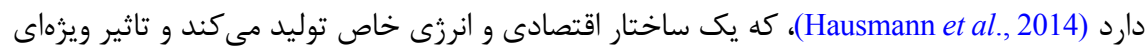
بر محيطزيست مى كذارد. محصولات يِيجيده عمدتاً نتايج توليد صنعتى يا بخش هاى شيميايى هستند

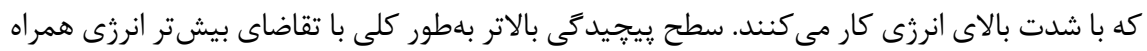
است. به منظور اطمينان از انرزى لازم و كاهش تاثيرات زيستمحيطى، كشورها بايد بسته به منابع

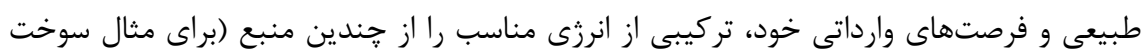

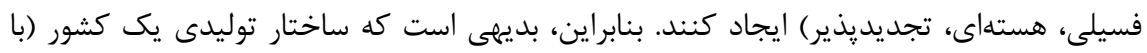
بخشهاى صنعتى و شيميايى با انرزى زياد) بر محيطزيست تاثير مى گذارد. به عبارت ديخر، سطح

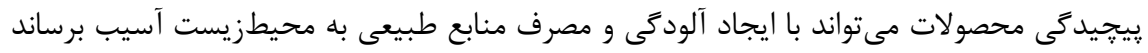
Can \& Gozgor, 2017; Neagu Teodoru, 2019) و نوآورى را در خود جاى داده است، كه مىتواند به معرفى فناورىهاى سازگًار با محيطزيست در فرايند توليد كمك كند و همجنين تاثيرات زيستمحيطى محصولات پيجٍيده جديد را در مرحله اوليه طراحى برنامهريزى نمايد. پيجيدگى اقتصاد از طريق شاخص ييجيدگى اقتصادى' (ECI)

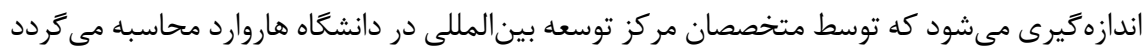
(Atlas of Economic Complexity, 2020) محصولات يِيجيده بيان مى كند و ميزان دانش توليدى جاسازىشده را در آن كشور تخمين مىزند. به ريه

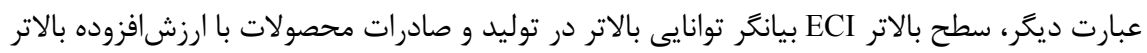


يا بيجيدهتر است (Hausmann et al., 2014). مصرف انرزى مبتنى بر سوختهاى فسيلى و توسعه اقتصادى مههمترين شاخصهاى اقتصاد كلان

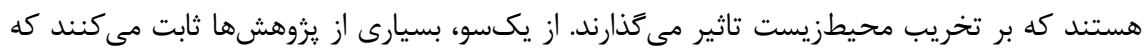
Saboori \& Sulaiman,) افزايش استفاده از سوختهاى فسيلى كيفيت محيطزيست را كاهش مى 2013; Bölük \& Mert, 2014 درجه دوم U-شكل معكوس بين توسعه اقتصادى و شاخصهاى آلودگى محيطى مانند دى اكسيد گوكرد

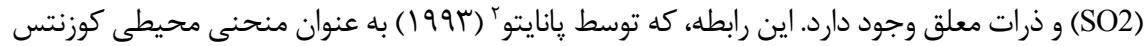
توصيف شده است، حاكى از اين است كه با افزايش سطح درآمد در مراحل اوليه توسعه اقتصادى،

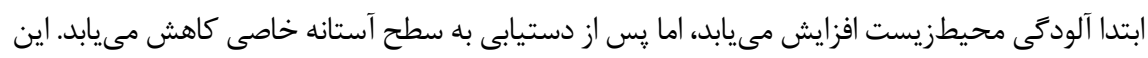
كزاره نظرى بيان مى كند كه محيطزيست بدتر مىشود، زيرا فشار محيطى در مراحل اوليه رشد اقتصادى

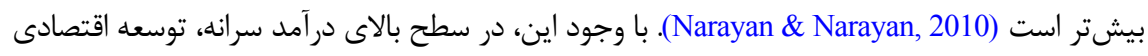

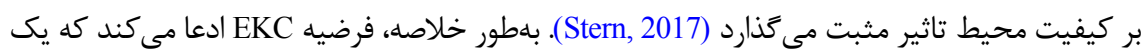

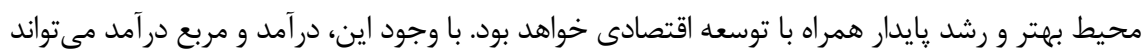
همبسته باشد. هنگَام بررسى فرضيه EKC، استفاده از مدلهاى مكعبى يا درجه دوم مى تواند باعث ايجاد

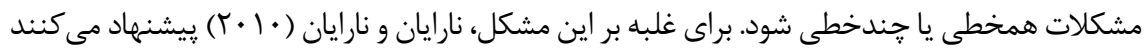

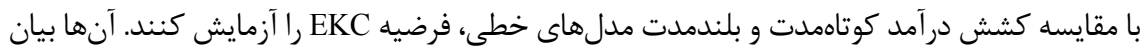
مى كنند كه آر مشخص شود كشش درآمد كوتاهمدت از كشش بلندمدت بالاتر است، اين نشان مى دهد كه

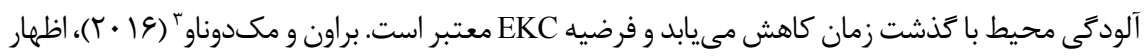

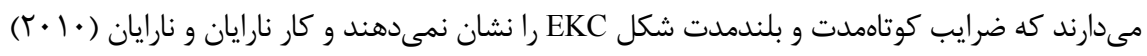

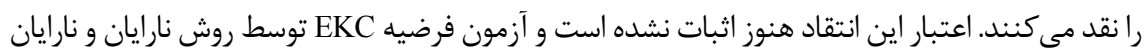

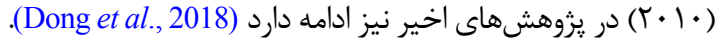

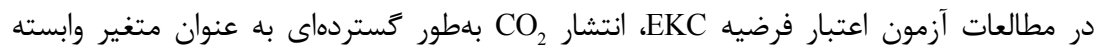

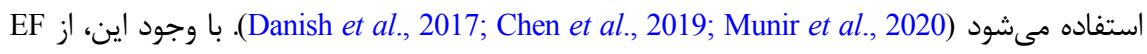
نيز براى آزمون فرضيه EKC به عنوان شاخص آلودگى محيطزيست بكار مىرود (Liu et al., 2018)

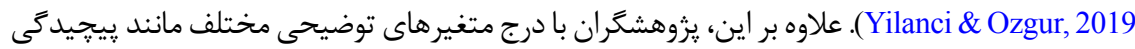

1. Grossman \& Krueger 
اقتصادى، جهانىسازى، و دموكراتيزهسازى و همجنين درآمد و مصرف انرزى، اعتبار فرضيه EKC

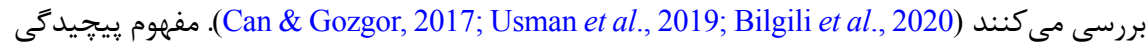

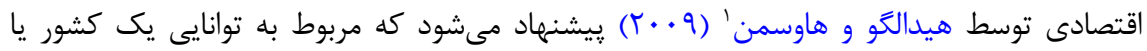

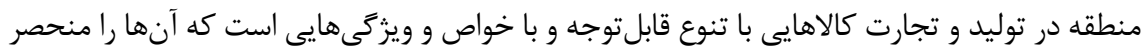

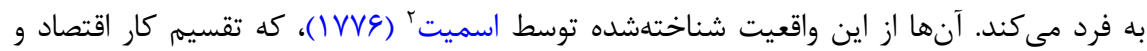
Romer, 1990;) مزاياى آن تحت تاثير تعاملات بين همه فعاليتهاى اقتصاد است، استفاده مى منى Grossman \& Helpman, 1991

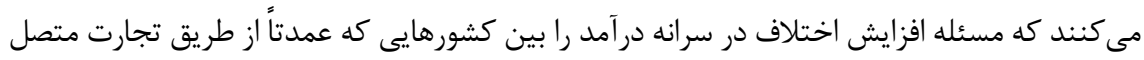

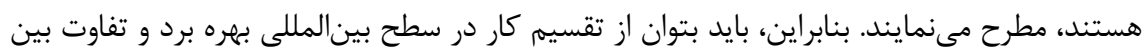

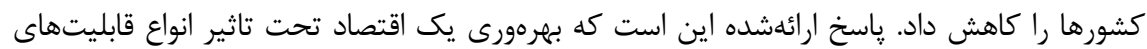

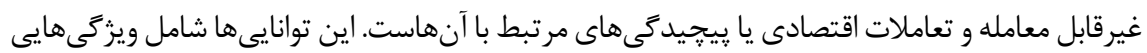
مانند كيفيت كار و مهارتهاى آن، جارجوب قانونى و نهادى، و زيرساختهاست. بلهور خلاصه،

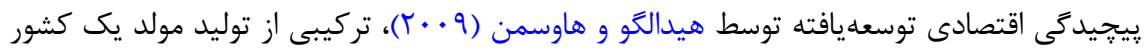
است. به عبارت ديگر، اين اندازهيرى توانايى كشور براى توليد محصولاتى با ارزش و بهرهورى بالاست (Hausmann et al., 2014). در جامعهاى با ورودىهاى ييشرفته، سطح توليد مولد افزايش مى يابد. ورودىها شامل سطح دانش و مهارتهايى مانند فناورى، سرمايه انسانى، نهاد و سيستم حقوقى هستند

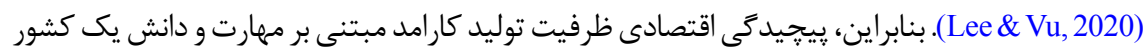

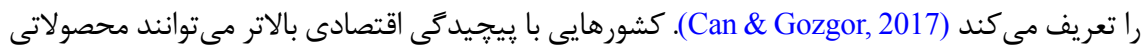

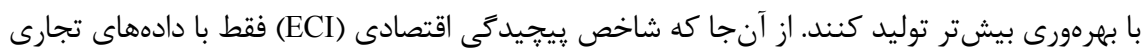

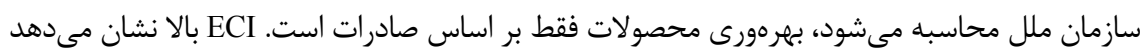
كه هم محصولات با بيجيدگ

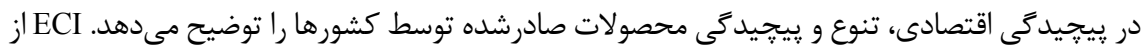

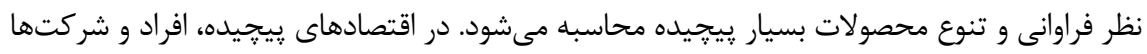
محصولات متنوعترى با شبكههاى بزرى و دانش و مهارت هاى جامع توليد مى كنند. برعكس، اقتصادهاى

1. Hidalgo \& Hausmann

2. Smith

3. Maddison

4. Pritchett 
سادهتر و در يك فضاى محدود، محصولات سادهتر و كمترى توليد مى كنند. در اين زمينه، پيجِيدگى

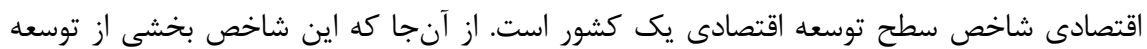

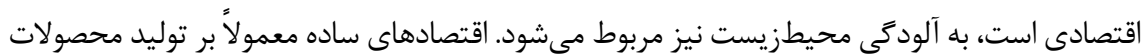
كشاورزى و مواد معدنى خام متمركز هستند، بنابر اين باعث تخر يب محدود محيطزيست مى ميوند. با اين

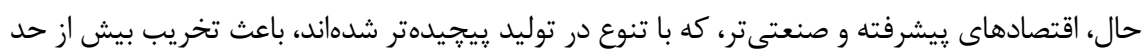
محيط مىشوند (Swart \& Brinkmann, 2020). سر انجام، در سطوح بالاى يِيجِيدكى اقتصادى، اقتصادها با توسعه سطح فناورى و دانش خود، از نظر محيطزيست ساز گارتر مىشوند. در جنين مرحلهاى، كشورها

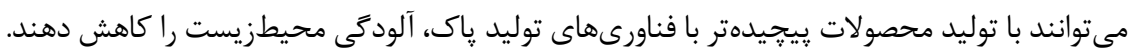

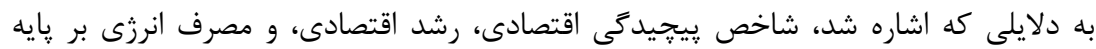
سوختهاى فسيلى مىتواند بر فشار محيط تاثير بخذارد. بلويزه در كشورى مثل ايران كه تمركز اصلى بر مصرف سوختهاى فسيلى است و توسعه اقتصادى بيشتر وابسته به صادرات نفت است و

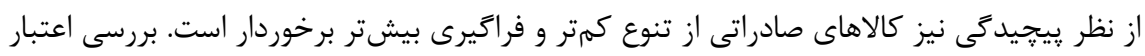

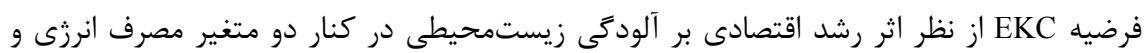

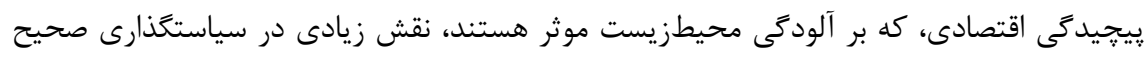
مسئولان اقتصادى در زمينه دستيابى به اهداف رشد و توسعه يايدار مىتواند داشته باشد. در اين

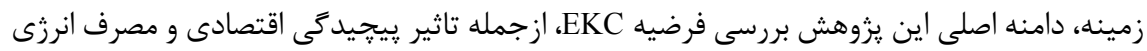

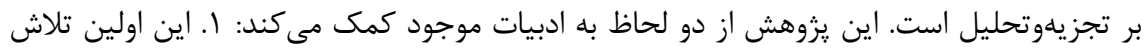

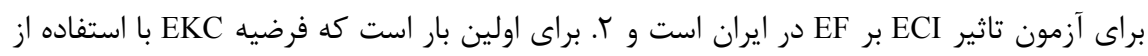

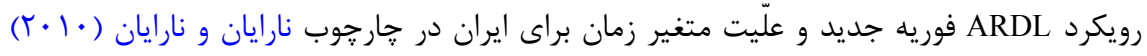
بررسى مىشود. در نتيجه، انتظار مىرود اين يزوهش ادبيات موجود را غنى كند.

\section{مبانى نظرى ثزووهش}

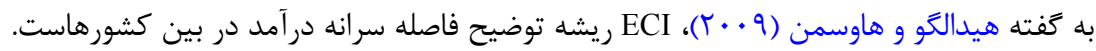

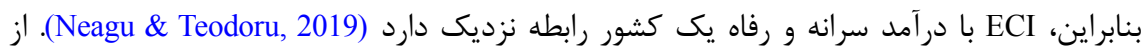

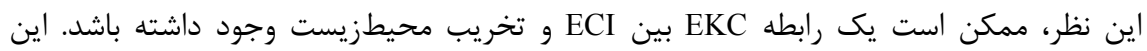

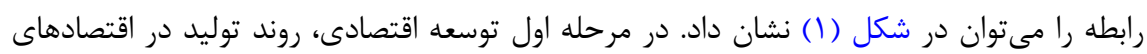

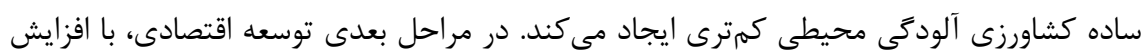


صنعتى شدن و تنوع محصول، اقتصادها يِيجِيدهتر مىشوند. در اين حالت، ECI كم و متوسط تخريب

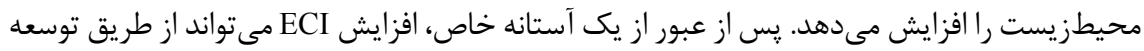
فناورى، دانش، و سرمايه انسانى از تخريب محيط جلوكيرى كند (Swart \& Brinkmann, 2020). فناورىهاى جديدى كه با تغيير ساختارى در اين فرايند ظهور مى كنند، جايكزين فناورىهاى قديمى مىشوند كه باعث آلودگى محيطزيست مى شوند. بنابراين، ECI متوسط و بالا فناورىها و دانش تميزترى را براى بهبود استانداردهاى زيستمحيطى ارائه مى دهد.

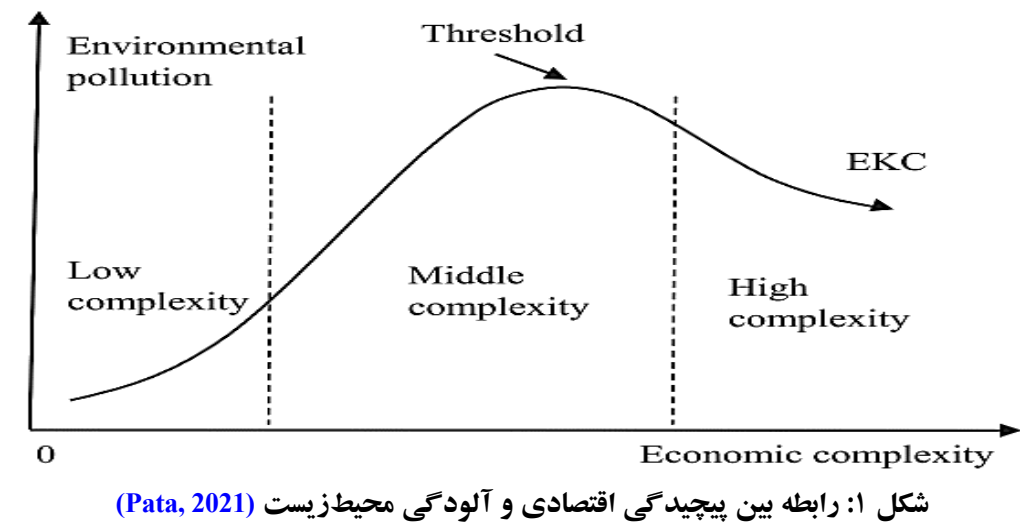

در بخش مقدمه، به يزوهشهاى مختلفى اشاره شد كه اعتبار فرضيه EKC را با استفاده از انتشار EF و به عنوان يك متغير وابسته بررسى مى كنند. تعداد مطالعات آزمون فرضيه EKC $\mathrm{CO}_{2}$ حال افزايش است. از آنجا كه يزوهشهاى زيادى در مورد بررسى فرضيه EKC وجود دارد، فقط بر ادبيات خاص تمركز مىشود. در يزوهش حاضر، بخش ادبيات نظرى به دو بخش تقسيم مىشود: 1.

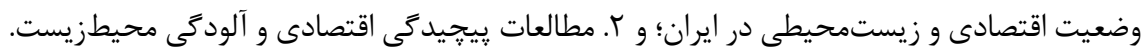

\section{وضعيت اقتصادى و زيستمحيطى در ايران}

بر اساس شاخص عملكرد محيطزيست، بررسى عملكرد محيطزيست نشان مى دهد كه ايران در سال

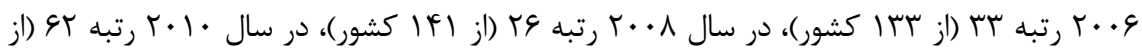

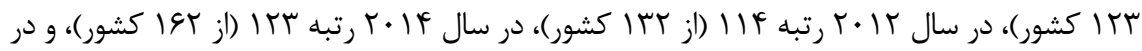




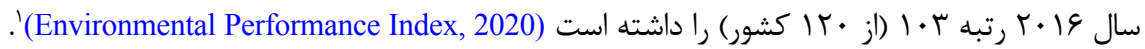

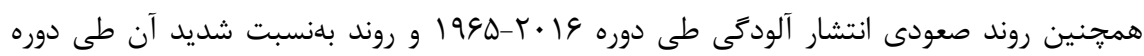

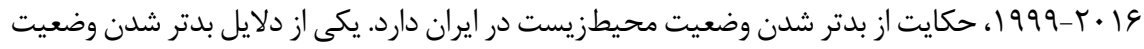
محيطزيست در ايران را مىتوان به نبود توجه كافى به اتخاذ يك سياست زيستمحيطى مناسب نسبت

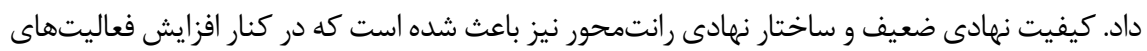
اقتصادى، ميزان انتشار آلودكى افزايش و كيفيت محيطزيست و در نهايت، رفاه اجتماعى تنزل يابد.

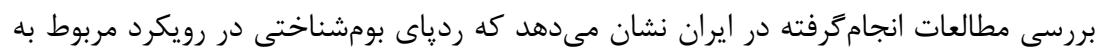

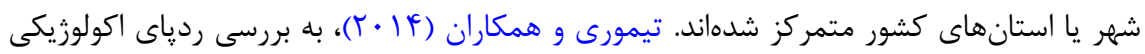

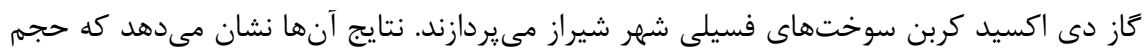

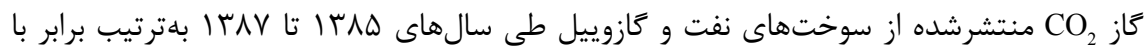

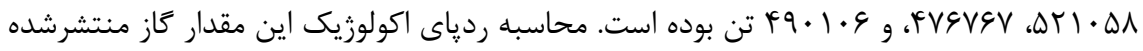
نيز نشان مى دهد، كل اراضى جنكلى مورد نياز براى جذب كاز دى اكسيد كربن حاصل از سوختن

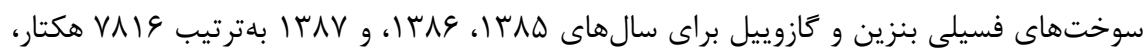

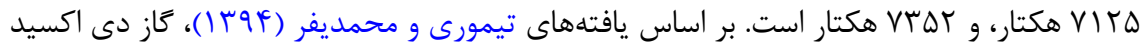

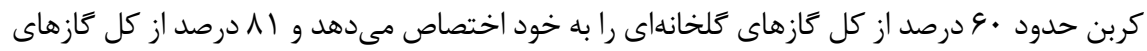

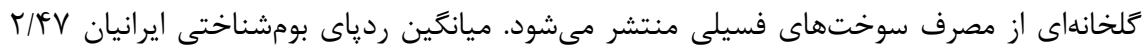

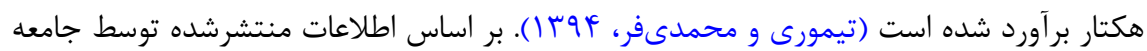

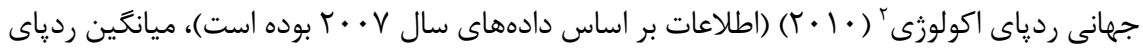

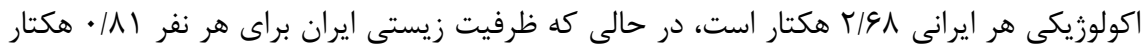

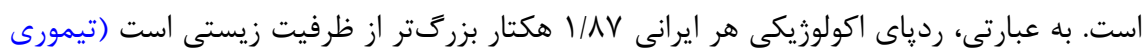

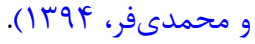
با توجه به بررسىها تنها يزوهش در خصوص ردياى بومشناختى مربوط به طرازكار و همكاران

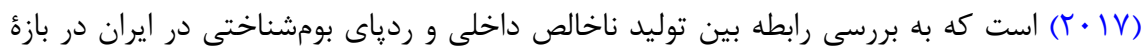

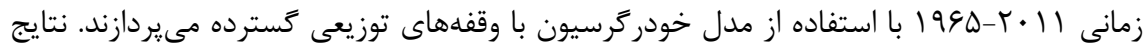

ا. علت كاهش رتبه ايران و بدتر شدن وضعيت طى اين سال ها، عموماً به واسطئ شاخصهاى بهداشت و سلامت 
آنها نشان مىدهد كه توليد ناخالص داخلى اثر مثبتى بر ردياى بومشناختى دارد. يزوهش ديكر

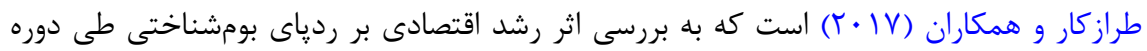

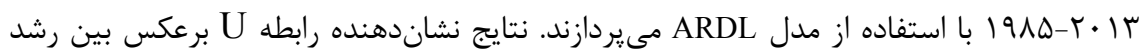
اقتصادى و ردياى بومشناختى است، و رشد اقتصادى اثر مثبتى بر آلودىى محيطزيست دارد.

\section{ييجِيد}

در كشور ايران تنها مطالعه انجامگرفته در رابطه با تاثير يِيجيدگى اقتصادى بر آلودگى محيطزيست

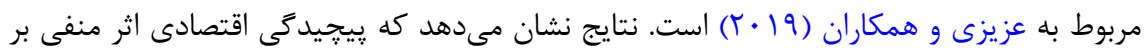
آلودگى محيطزيست دارد. همجنين، اعتبار فرضيه منحنى زيستمحيطى كوزنتس مونس مورد تاييد قرار

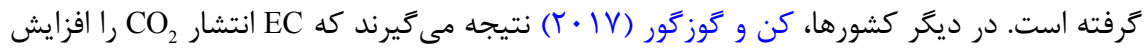
مىدهد، در حالى كه يِيجيدگى اقتصادى آلودگى محيطزيست را سركوب مى كند. يافتههاى اين مطالعه اعتبار فرضيه EKC را براى فرانسه تاييد مى كند. علاوه بر اين دوكان و همكاران' (19 • (Y)، نشان مى دهند كه فرضيه EKC در كشورهايى با در آمد بالا معتبر است، در حالى كه بين انتشار

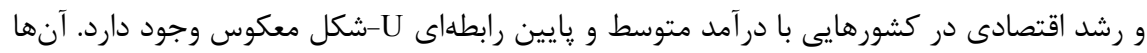

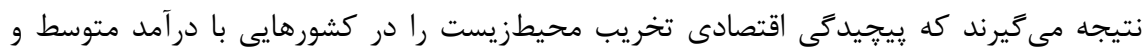

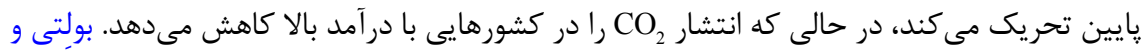

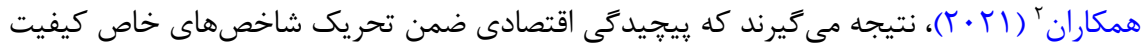

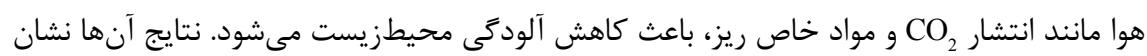

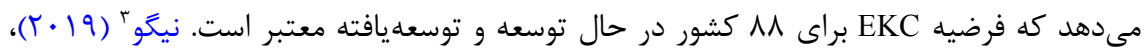

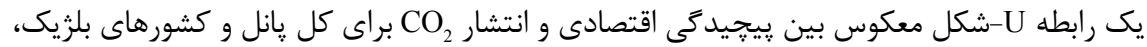

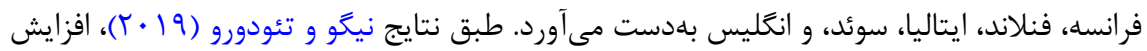

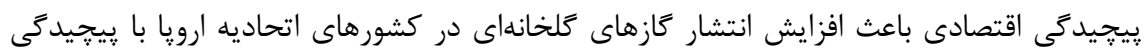

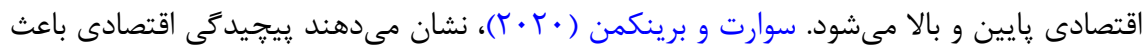

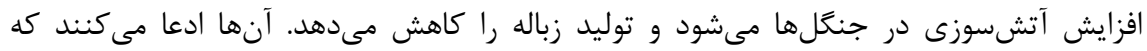
ييجيدگى اقتصادى هيج تاثيرى بر تخريب جنگل ها و آلودىى هوا در برزيل ندارد. نتايج اين مطالعه

1. Doğan et al.

2. Boleti et al.

3. Neagu 


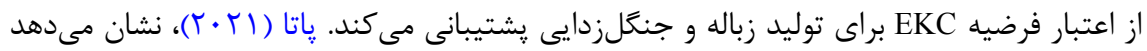

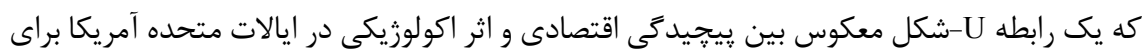

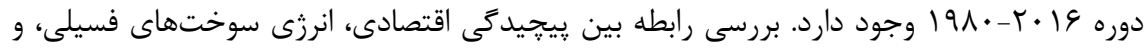

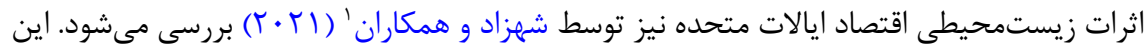
يروهش تاييد مى كند كه ييجيدگى اقتصادى و مصرف انرزى سوختهاى فسيلى باعث افزايش ردياى اكولوزيكى مىشود.

\section{داده و روشهاى اقتصادسنجى}

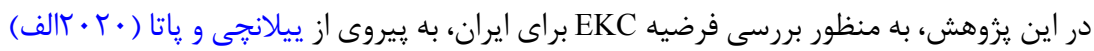
از مدل (1) استفاده مىشود.

$\ln E F_{t}=\beta_{1}+\beta_{2} \ln G D P_{t}+\beta_{3} \ln E C_{t}+\beta_{4} \ln E C I_{t}+u_{t}$

(ECI و ECF ، EC ، EC

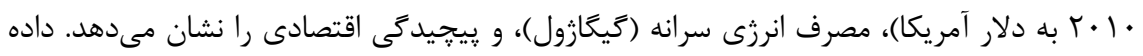

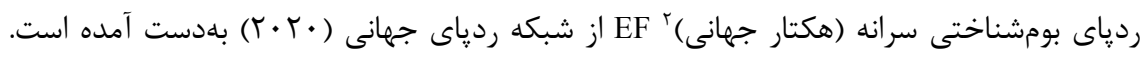
دادههاى توليد ناخالص داخلى از شاخصهاى توسعه جهانى (https:/data.worldbank.org) كرفته شده است. دادههاى مصرف انرزى سرانه (EC) از بررسى آمارى مرور آمارى نفت بريتانيا از انرزى لـى جهانى " (BP, 2019) استخراج شده است و شامل كل انرزى مصرفشده اعم از نفت، فسيلى، برقى،

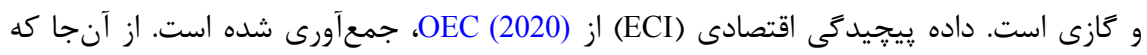

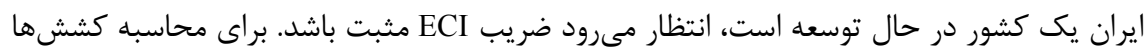

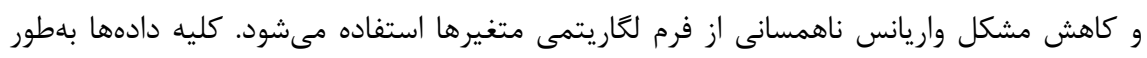

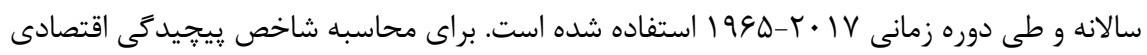

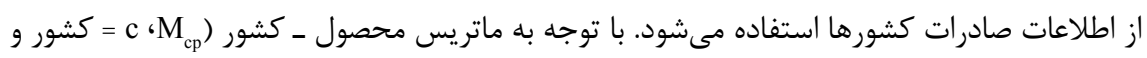

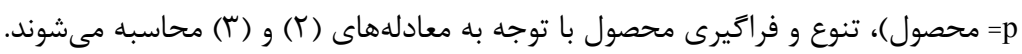

تنوع $=k_{c 0}=\sum_{p} M_{c p}$

فراگير $=k_{p 0}=\sum_{p} M_{c p}$

1. Shahzad et al.

r. در مورد شاخص به يزوهش طرازكار و همكاران (Y. P (Y) مراجعه شود. 3. British Petroleum Statistical Review of World Energy 


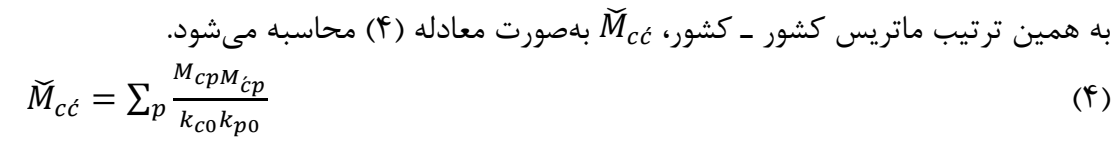

در نهايت، شاخص ييجيدگى اقتصادى براى هر كشور بر اساس معادله (ل) محاسبه مىشود. $E C I=\frac{\vec{K}-<\vec{K}>}{\operatorname{se}(\vec{K})}$

در رابطه (ل) نماد > > معرف ميانگين، se نشاندهنده انحراف معيار، و دومين بزرگترين مقدار ويزه ماتريس

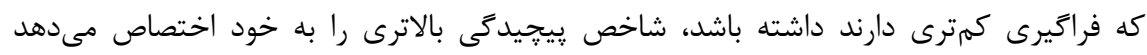

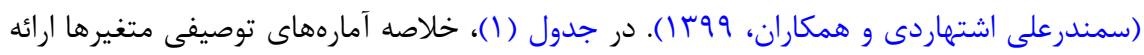

شده است.

جدول ا: خلاصه آمارههاى توصيفى متغيرها به صورت لكاريتم

\begin{tabular}{|c|c|c|c|c|c|}
\hline تعداد مشاهدهها & Std.Dev & $\min$ & Max & Mean & متغيرها \\
\hline$\Delta r$ & .194 & T/99 & $4 / 94$ & $r / \cdot r$ & $\mathrm{EC}$ \\
\hline$\Delta r$ & . & אس/. & $T / Q F$ & $\cdot / V 8$ & ECI \\
\hline$\Delta r$ & $\cdot / 4 \wedge$ & $-\cdot / 19$ & I/T & $\cdot / \Delta V$ & $\mathrm{EF}$ \\
\hline$\Delta r$ & $\cdot \mid \Delta F$ & IV/99 & $1 / N / V$ & $1 / 1 \mid$ & GDP \\
\hline
\end{tabular}

بر اساس نتايج جدول (1)، ميانكين توليد ناخالص داخلى سرانه |N/1 است و ميانغين مصرف

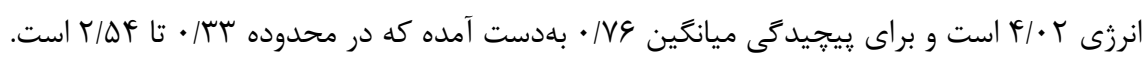

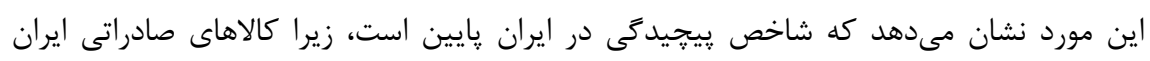

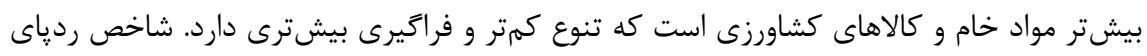

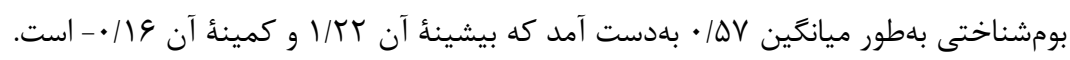

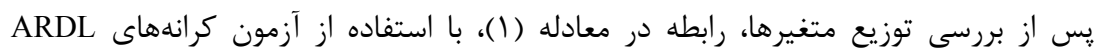

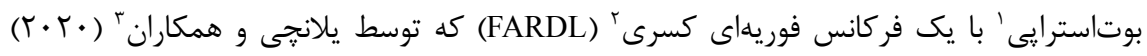

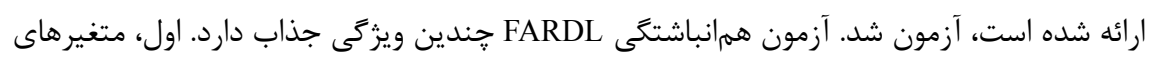

1. Bootstrap ARDL Bounds Test

2. Fractional Fourier Frequency

3. Yilanci et al. 
توضيحى مىتوانند (1)I ب) باشند. دوم، اين آزمون اجازه مىدهد كه شكستهاى ساختارى

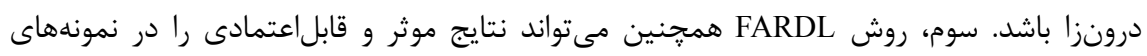

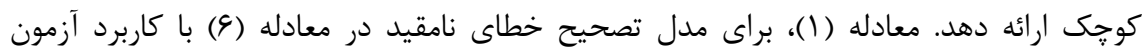
FARDL به صورت زير بازنويسى مىشود.

\section{$\Delta L E F_{t}=$}

$d(t)+\beta_{2} \ln E F_{t-1}+\beta_{3} \ln G D P_{t-1}+\beta_{4} \ln E C_{t-1}+\beta_{5} \ln E C I_{t-1}+$

$\sum_{i=1}^{P} \alpha_{i}^{\prime} \Delta \ln E F_{t-i}+\sum_{i=0}^{q} \delta_{i}^{\prime} \Delta \ln G D P_{t-i}+\sum_{i=0}^{w} \varphi_{i}^{\prime} \Delta \ln E C_{t-i}+\sum_{i=0}^{v} \phi_{i}^{\prime} \Delta \ln E C I_{t-i}+e_{t}$

هو p بهترتيب عملكر تفاضل و طول وقفه هستند. d(t) عبارت جبرى است كه به اين صورت

$$
\text { تعريف مىشود: }
$$

$d(t)=\beta_{0}+\gamma_{1} \sin \left(\frac{2 \pi k t}{T}\right)+\gamma_{2} \cos \left(\frac{2 \pi k t}{T}\right)$ or $d(t) \beta_{0}+\beta_{1} t+\gamma_{1} \sin \left(\frac{2 \pi k t}{T}\right)+\gamma_{2} \cos \left(\frac{2 \pi k t}{T}\right)$

k k ، يك فر كانس خاص است كه براى تقريب شكستهاى ساختارى استفاده مىشود

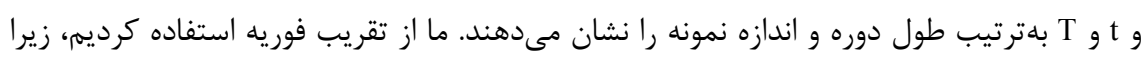

اين تابع مىتواند تعداد ناشناختهاى از شكستها را از تغييرات ساختارى تدريجى و شديد ثبت دون

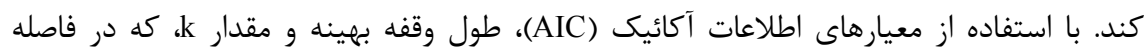

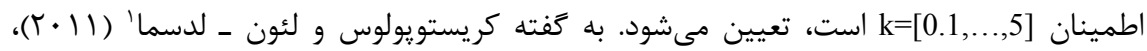
فركانسهاى عدد صحيح براى شكستهاى موقت مفيد هستند، در حالى كه فركانسهاى كسرى دلالت بر شكستهاى دائمى دارند.

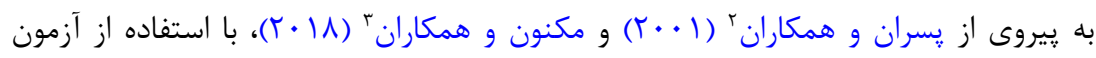

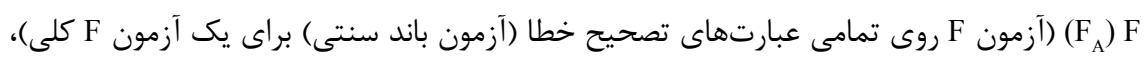

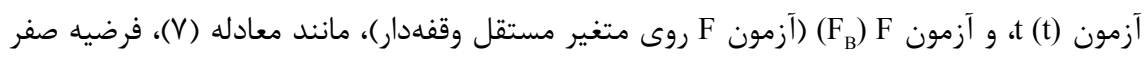
يعنى عدم رابطه همانباشتخى بررسى مى شود (مها ضرايب متغيرهاى توضيحى هستند). $H_{0 A}: \beta_{1}=\beta_{2}=\beta_{3}=0, H_{0 t}: \beta_{1}=0, H_{0 B}: \beta_{2}=\beta_{3}=0$.

نتايج آزمون F و Fهار مورد مختلف ايجاد كرد:

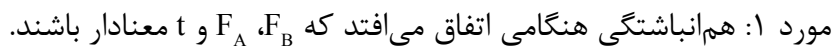

1. Christopoulos \& Leon-Ledesma

2. Pesaran et al.

3. McNown et al. 


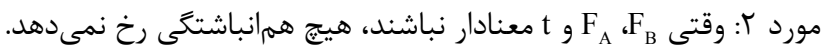

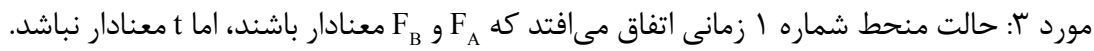

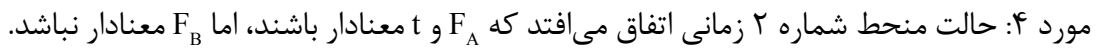

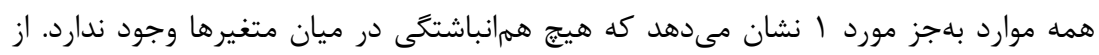

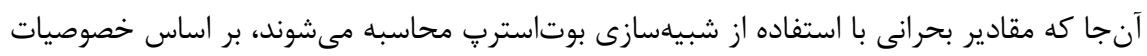

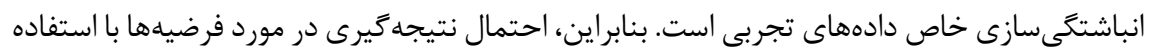

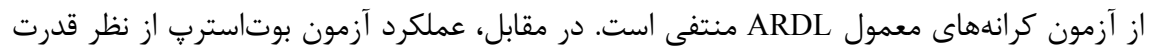

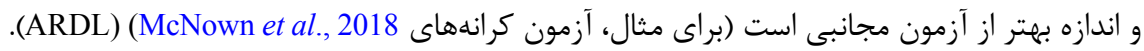

\section{نتايج تجربى}

وقتى هر كدام از متغيرهاى موجود در تجزيهوتحليل در تفاضل دوم پايا باشند (I(2)) از روش

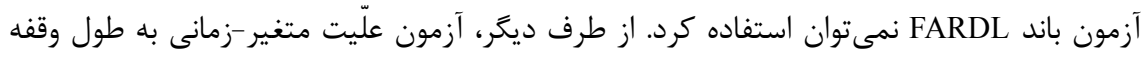
بهينه حساس است، كه با توجه به ترتيب انباشتكى متغيرها تغيير مى كند. بنابراين، اولين مرحله از

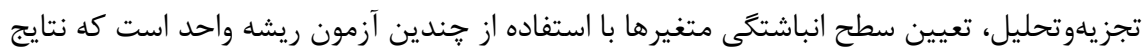

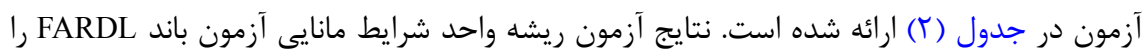

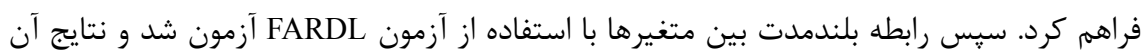
در جدول (r) ارائه شد. 


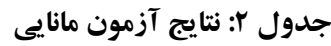

\begin{tabular}{|c|c|c|c|c|}
\hline \multicolumn{2}{|c|}{ فيلييس - يرون } & \multicolumn{2}{|c|}{ ديكى - فولر } & \multirow[b]{2}{*}{ متغير } \\
\hline يكبار تفاضل & در سطح & يكبار تفاضل & در سطح & \\
\hline$*-r / \Delta) \cdot V \wedge r$ & -1/AIFrTq & $*-4 / f q r q \wedge q$ & $-r / 1 Y \cdot r r$ & GDP \\
\hline$*-1.1994 . r$ & $-\cdot / r \mid r A v e$ & $*-V / r q \mu \cdot q 4$ & $-.194 \wedge 19 \vee$ & $\mathrm{EF}$ \\
\hline *-D/VAFrTV & $-T / r \cdot \Lambda F r r$ & *-D/VAFrTV & $-r / 4 \cdot 09 \cdot 9$ & EC \\
\hline *-F/GAFFTH & . $/ r q 9|r|$ & *-F/VFY१९Q & -I/IVFFYY & ECI \\
\hline
\end{tabular}

توضيح: ** مانايى در سطح ادرصد.

نتايج آزمون FARDL نشان مىدهد كه فركانس بهينه // است كه نشاندهنده شكست دائمى

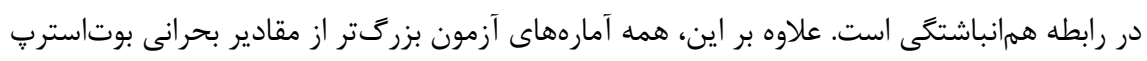
در سطوح معمول است، بنابراين، نتيجه مى گيريم كه يك رابطه بلندمدت ميان متغيرها وجود دارد. جدول rّ: نتايج آزمون همانباشتكى FARDL بوتاسترب

\begin{tabular}{|c|c|c|c|c|}
\hline & AIC & $\mathbf{K}$ & \multicolumn{2}{|c|}{ انتخاب مدل } \\
\hline & $-T / T \wedge \wedge \Delta \Delta q$ & 1/1 & \multicolumn{2}{|c|}{ FARDL $(2,0,0,0)$} \\
\hline \multicolumn{3}{|c|}{ مقادير بحرانى بوتاستر } & \multicolumn{2}{|c|}{ آماره آزمون } \\
\hline .199 & $\cdot / 90$ & $\cdot / 9$. & & \\
\hline N/QTAIV & 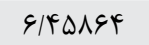 & D/IVTAF & $9 / 9 T \cdot A V$ & FA \\
\hline$-4 / 94991$ & $-r / 94919$ & $-r / f q V \cdot r$ & -F/MYTTD & $\mathrm{T}$ \\
\hline$V / T \cdot 91 \mathrm{~V}$ & Q/. ITST & r/A A^V & D/qArqF & $\mathrm{FB}$ \\
\hline
\end{tabular}

نتايج بر آورد بلندمدت و كوتاممدت در جدول (†) ارائه شده است. ضرايب بلندمدت نشان مى دهد

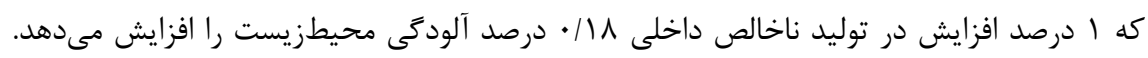

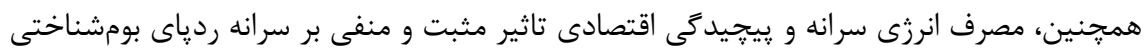

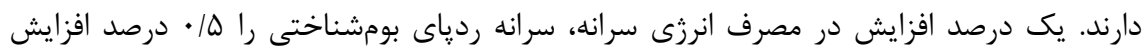

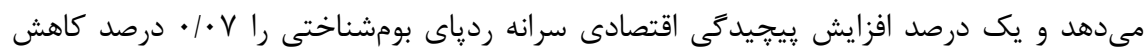

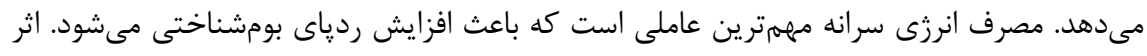


مثبت مصرف انرزى بر آلودگى در ايران با يافتههاى حرى و همكاران (با • (Y)، ترابى و همكاران

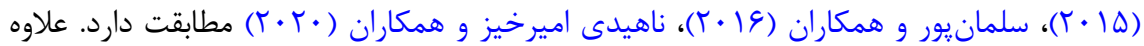
بر اين، بهرهورى انرزى ايران بسيار كم است. به همين دلايل، مصرف انرزى اوليه ايران همجنان فشار

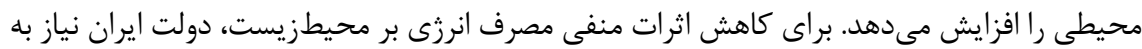

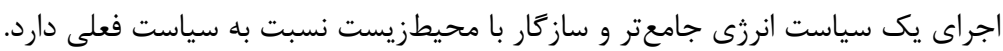

جدول f: نتايج تخمين بلندمدت و كوتاهمدت

\begin{tabular}{|c|c|c|}
\hline 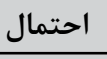 & ضرايب & متغير \\
\hline \multicolumn{3}{|c|}{ ضريب بلندمدت بر اساس روش FARDL } \\
\hline $.1 \ldots$ & . MNFHF. & GDP \\
\hline$\cdot 1 \cdot r \cdot \Delta$ & $-\cdot / \cdot \vee \vee \wedge \wedge 1$ & ECI \\
\hline | & /D. & $\mathrm{EC}$ \\
\hline$\cdot 1 \cdot r \Delta$ & -I/ITATrq & Constant \\
\hline \multicolumn{3}{|c|}{ برآورد كوتاهمدت بر اساس مدل تصحيح خطا با تابع فوريه } \\
\hline$\cdot 1 \cdot \cdot r \Delta$ & 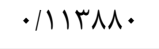 & $\Delta \mathrm{LGDPt}$ \\
\hline$\cdot 1 \cdots$ & $-\cdot|\cdot r| I \cdot V$ & $\Delta$ LECIt \\
\hline$\cdot / \cdot r G$. & $\cdot|\cdot f \wedge| r$ & $\Delta \mathrm{LECt}$ \\
\hline$\cdot 1 \cdot \cdots$ & $-1 / \cdot V F V \Delta s$ & $\gamma_{1} \cos$ \\
\hline $.1 \ldots$ & - /FVGrFq & $\gamma_{1} \sin$ \\
\hline $.1 \ldots$ & $-.191 \mathrm{VVVF}$ & ECTt-1 \\
\hline
\end{tabular}

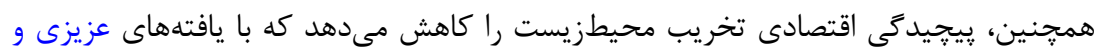

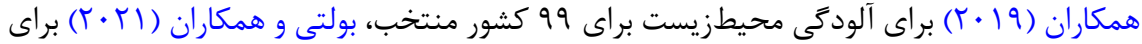

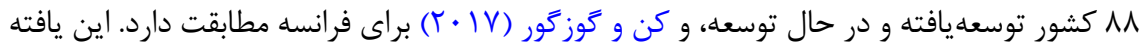
نشان مى دهد كه ايران محصولى را توليد مى كند كه باعث آلودگى محيطزيست نمى شود.

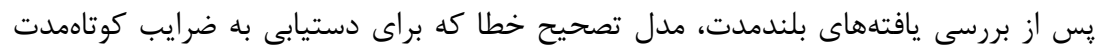
مبتنى بر روش FARDL است، تخمين زده شد. نتايج نشان مىدهد در حالى كه توليد ناخالص

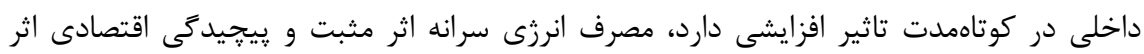


منفى بر ردياى بومشناختى دارند. ضريب عبارت تصحيح خطا (ECT) از نظر آمارى معنادار است

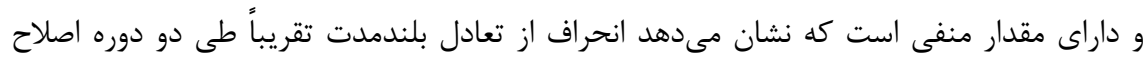

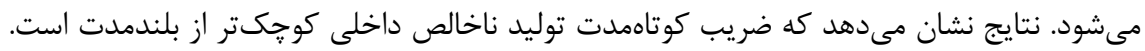

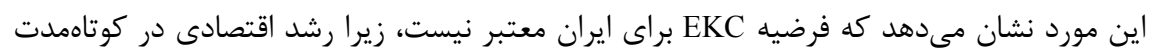

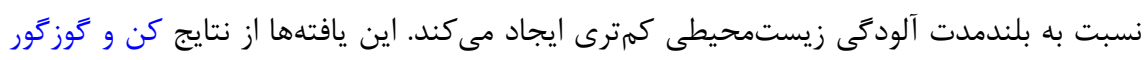

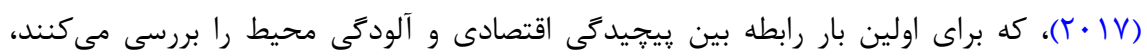

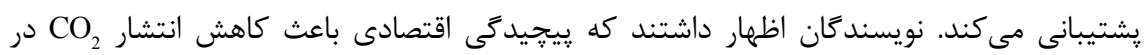

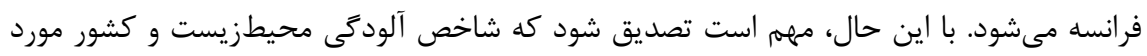

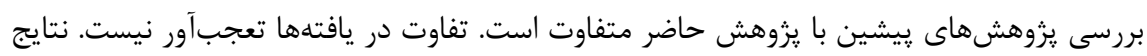

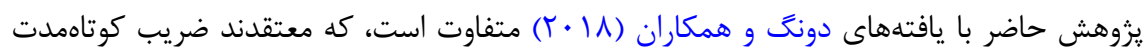

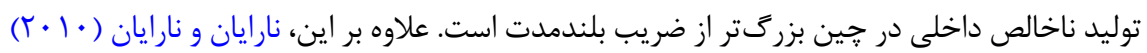

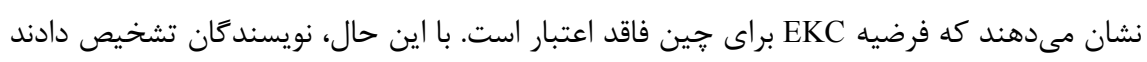

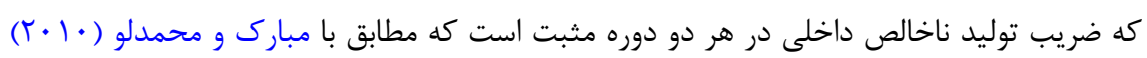

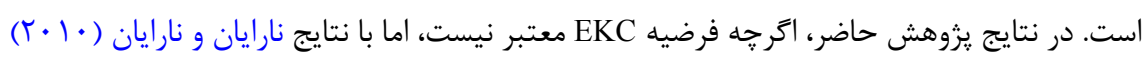
همراستاست.

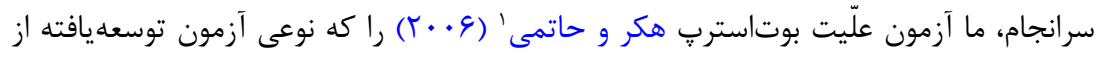

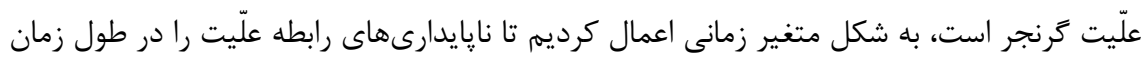

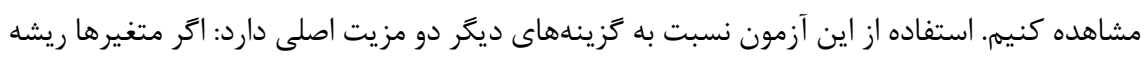

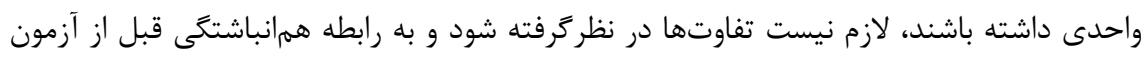

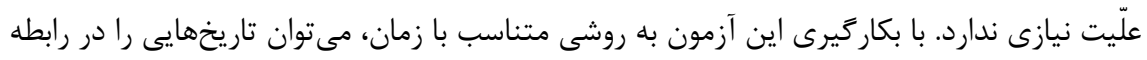

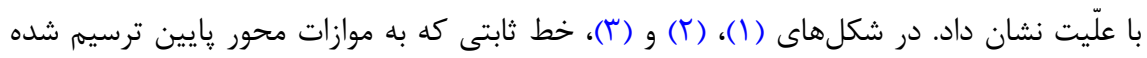

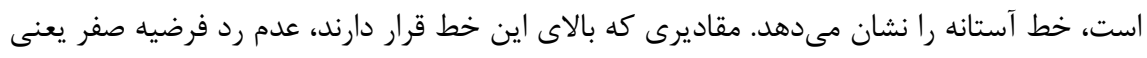
نبود علّيت را نشان مى دهد.

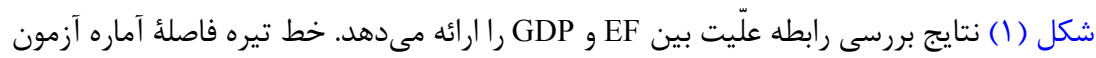

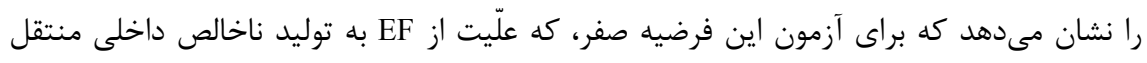

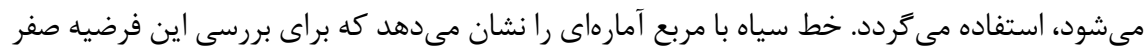


محاسبه مىشود كه هيج علّيتى از GDP تا EF وجود ندارد. نتايج نشان مى دهد كه يك رابطه علّيت از

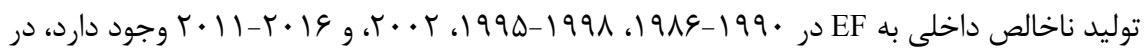

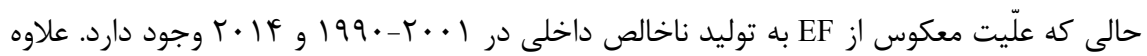

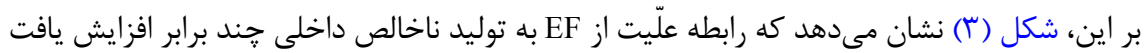

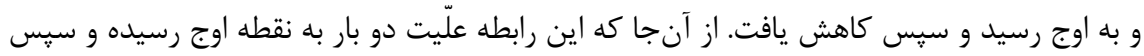

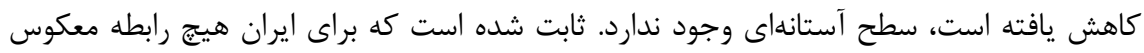

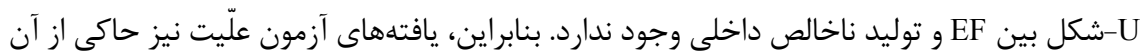
است كه فرضيه EKC در ايران معتبر نيست.

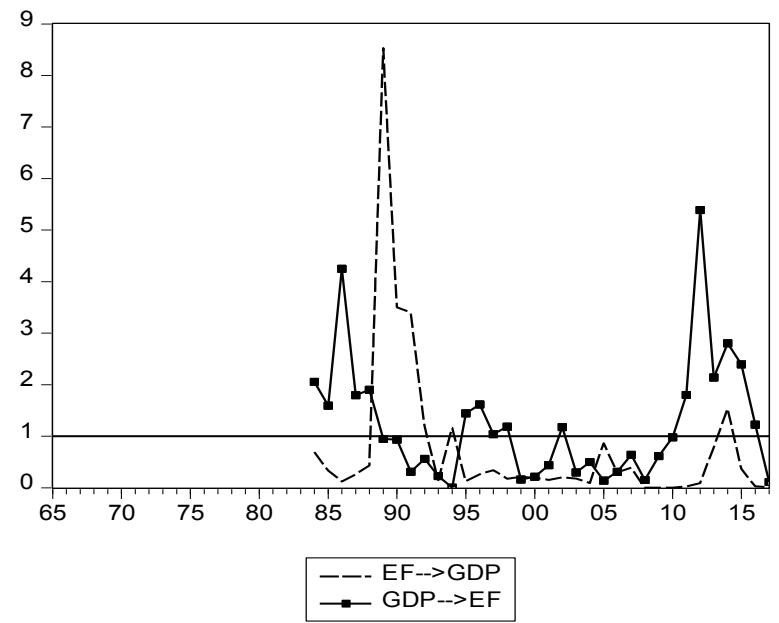

شكل ا: نتايج رابطه علّيت بين GDP و EF 
در ادامه ما رابطه علّيت را بين EF و EC بررسى كرديم. نتايج آن در شكل (r) ارائه شده است.

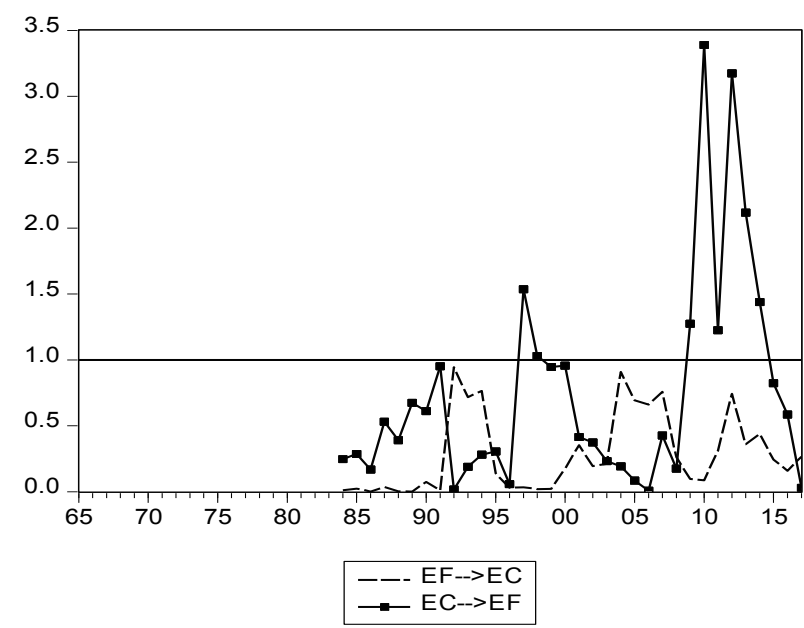

\section{شكل r: نتايج رابطه علّيت بين EC و EF}

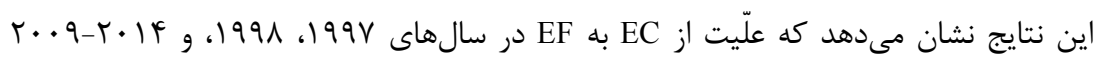

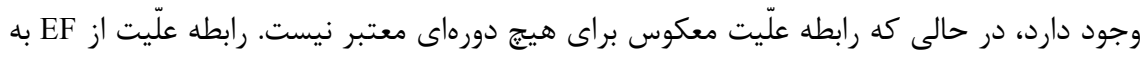

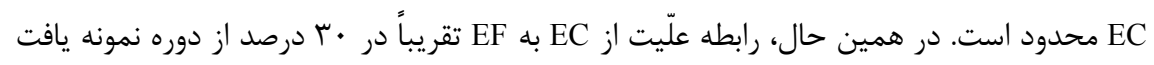
مىشود. اين مورد نشان مىدهد كه EC (مصرف انرزى سرانه) اوليه ايران باعث تخريب قابلتوجه

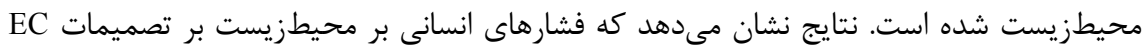
تاثير مى گذارد و EC باعث تخريب محيطزيست در سالهاى اخير شده است. شكل (Y)، شامل آمار

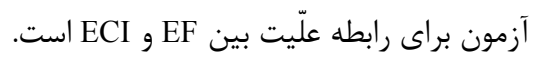




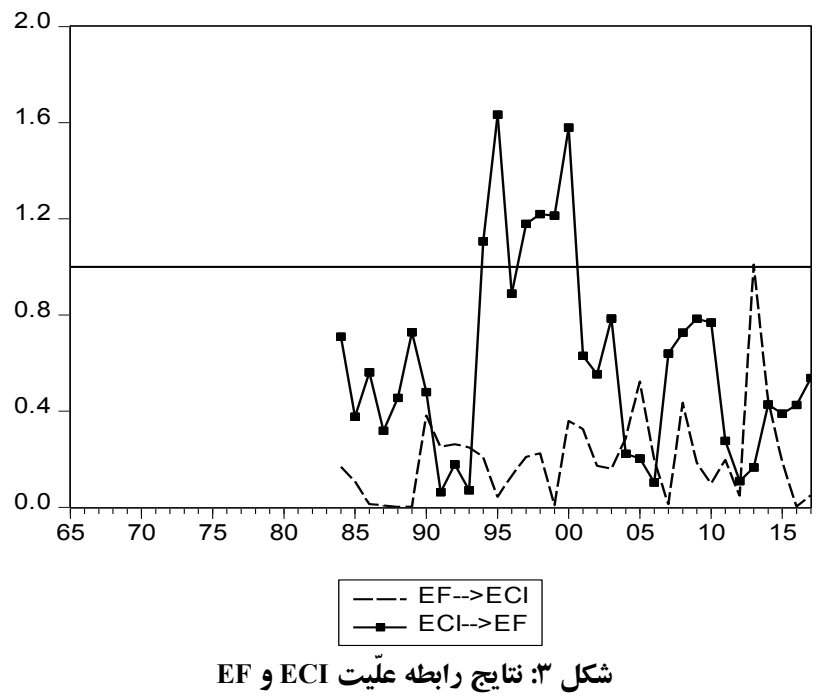

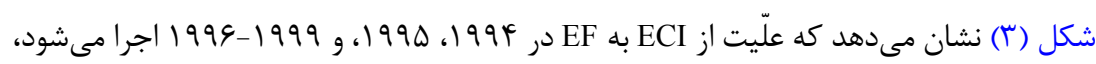

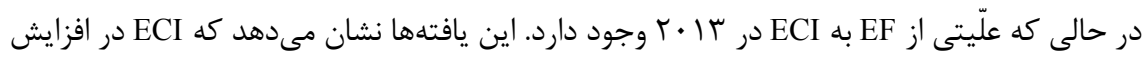
EF

\section{بحث و نتيجه كيرى}

در اين يزوهش تجربى، روابط بين سرانه ردياى بومشناختى، سرانه توليد ناخالص داخلى واقعى،

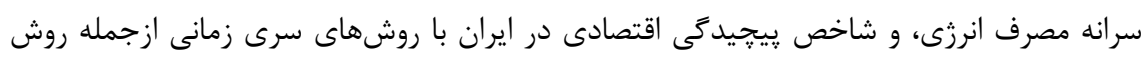

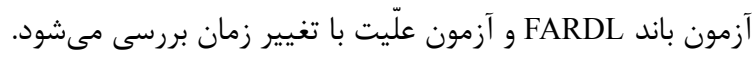

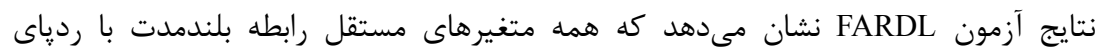

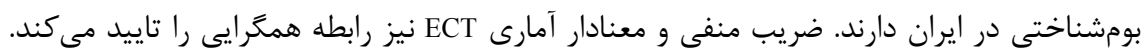

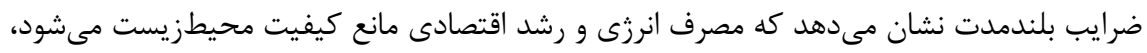

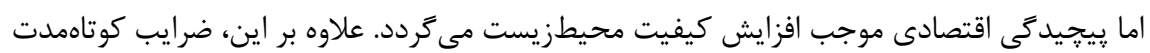
نشان مى دهد كه افزايش توليد ناخالص داخلى و مصرف انرزى باعث افزايش سرانه ردياى بومشنى

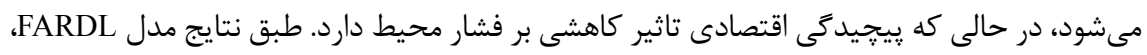

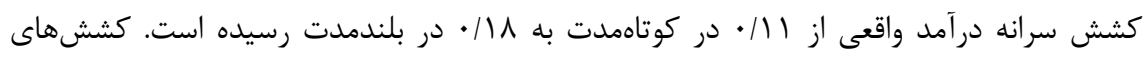


مثبت بلندمدت و كوتاهمدت درآمد از اعتبار فرضيه EKC يشتيبانى نمى كنند. اين يافتهها ثابت

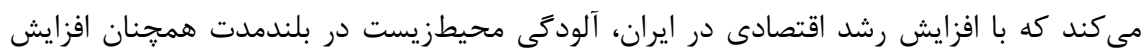

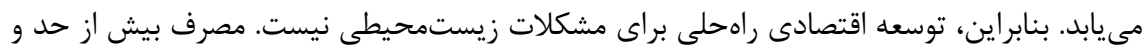

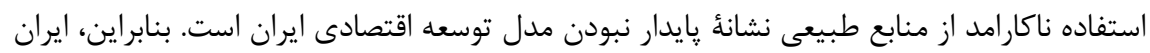

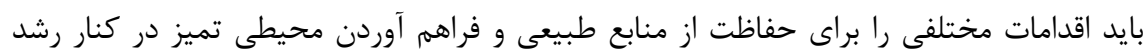
اقتصادى خود انجام دهد. براى مثال، دولت ايران لازم است از بهرهبردارى منابع نفتى و تكيه صادرات

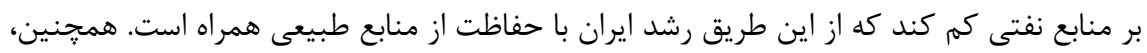

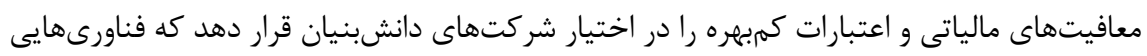
را در جهت كاهش تخريب محيطزيست توسعه مى دهند. علاوه بر اين، سياستخذاران مى متوانند سهرمه

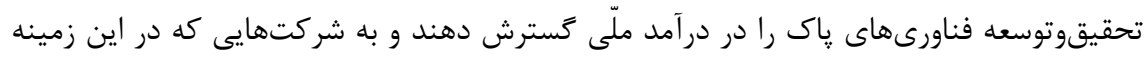
يزوهش مى كنند، يارانهاى نوآورانه بدهند.

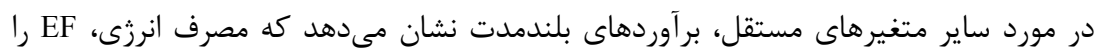

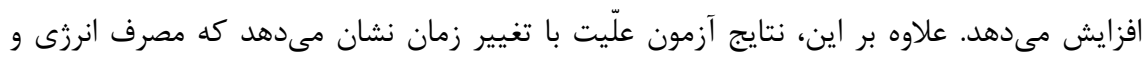
رشد اقتصادى باعث آلودگى محيطزيست در دورههاى خاص مىشود. در نتيجه، اين دو متغير باعث

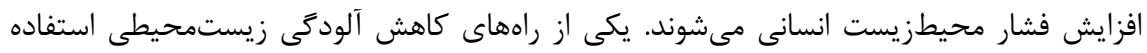

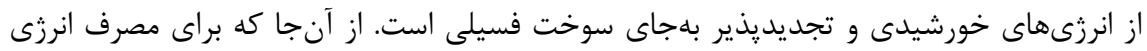
در اين يزوهش از انرزى مصرفشده شامل نفت، كاز و ساير سوختهاى فسيلى استفاده مىشود و ورى بر اساس نتايج، استفاده از سوختهاى فسيلى آلودگى محيطزيست را افزايش مى دهدد، لازم است

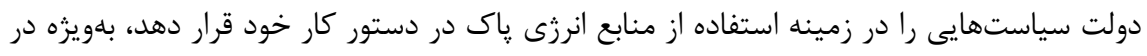

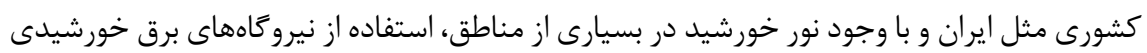
بهجاى نيروكاههاى سوخت فسيلى براى توليد برق مى تواند كمك زيادى به كاهش آلودگى و تخريب

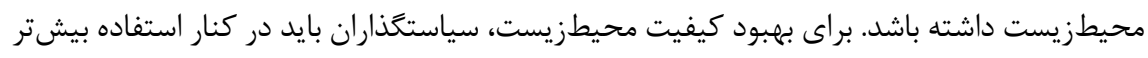

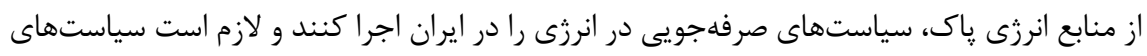

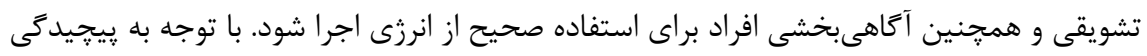
اقتصادى، بديهى است كه توليد صنايع سنگين ايران آلودكى محيطزيست را افزايش مى مدهد. ايران

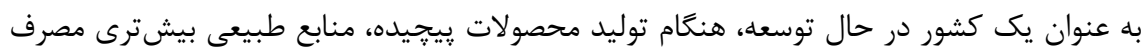

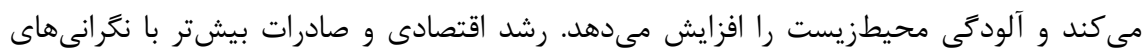


زيستمحيطى براى ايران همراه است و لازم است در كنار برنامههاى رشد و توسعه اقتصادى، رشد و

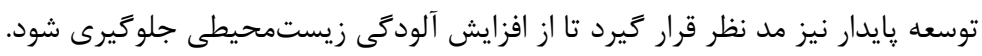

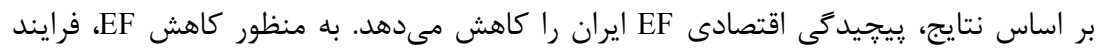
صادرات بايد با روشهاى سازگار با محيطزيست و فناورى انجام شود. البته در ايران هنوز زيجيدىى

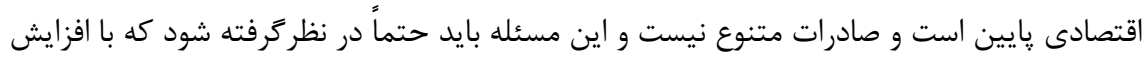
تنوع صادرات، مسائل زيستمحيطى و نحوه توليد محصولات در نظرگرفته شود تا افزايش ريبريدگى اقتصادى باعث افزايش آلودگى زيستمحيطى نشود.

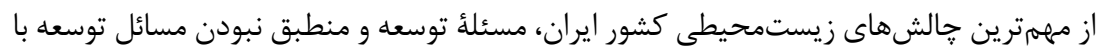
محيطزيست است كه با افزايش پيیجيدگى اقتصادى و توليد كالاهايى با فناورى بالاتر قطعاً اين مشكل نمود بيشترى پيدا مى كند. متاسفانه اين تعارضى است كه در كشورهاى در حال توسعه وجود دارد

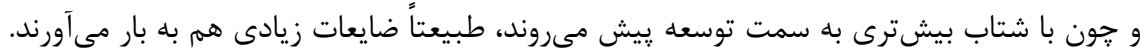
يكى از بزرگترين قربانيان اين توسعه، محيطزيست است و كشور ايران هم جدا از اين مقوله نيست. هماهنكى برنامهای توسعه با ضوابط زيستمحيطى يكى مفهوم كلى است كه در اصل • •ه قانون اساسى مورد توجه قرار گرفته است. در اصل •له كَفته شده است كه برنامههاى توسعه اجرا شوند، اما

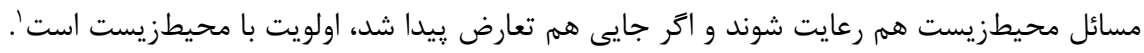

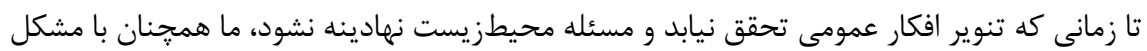

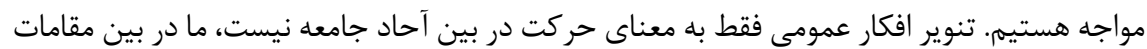

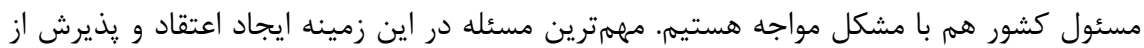

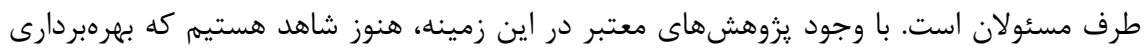

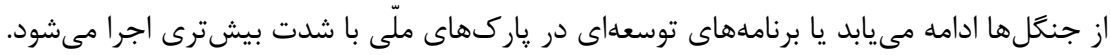

\section{منابع}

Atlas of Economic Complexity (2020). Available online: https://atlas.cid.harvard.edu/countries (Accessed on 20 July).

Azizi, Z., Daraei, F., \& Boroujeni, A. N. (2019). The Impact of Economic Complexity on Environmental Pollution. Economic Development Policy, 7(2), 201-219. 
https://dx.doi.org/10.22051/edp.2020.29451.1225

Bagliani, M., Bravo, G., \& Dalmazzone, S. (2008). A Consumption-Based Approach to Environmental Kuznets Curves Using the Ecological Footprint Indicator. Ecological Economics, 65(3), 650-661. https://doi.org/10.1016/j.ecolecon.2008.01.010

Bilgili, F., Ulucak, R., Koçak, E., \& İlkay, S. Ç. (2020). Does Globalization Matter for Environmental Sustainability? Empirical Investigation for Turkey by Markov Regime Switching Models. Environmental Science and Pollution Research, 27(1), 1087-1100. https://doi.org/10.1007/s11356-019-06996-w

Boleti, E., Garas, A., Kyriakou, A., \& Lapatinas, A. (2021). Economic Complexity and Environmental Performance: Evidence from a World Sample. Environmental Modeling \& Assessment, 26(3), 251-270. https://doi.org/10.1007/s10666-021-09750-0

Bölük, G., \& Mert, M. (2014). Fossil \& Renewable Energy Consumption, GHGs (Greenhouse Gases) and Economic Growth: Evidence from a Panel of EU (European Union) Countries. Energy, 74(1), 439-446. https://doi.org/10.1016/j.energy.2014.07.008

BP Statistical Review of World Energy (2019). Available at: https://www.bp.com/en/global/corporate/news-and-insights/press-releases/bp-statisticalreview-of-world-energy-2019.html

Brown, S. P., \& McDonough, I. K. (2016). Using the Environmental Kuznets Curve to Evaluate Energy Policy: Some Practical Considerations. Energy Policy, 98(1), 453-458. https://doi.org/10.1016/j.enpol.2016.09.020

Can, M., \& Gozgor, G. (2017). The Impact of Economic Complexity on Carbon Emissions: Evidence from France. Environmental Science and Pollution Research, 24(19), 1636416370. https://doi.org/10.1007/s11356-017-9219-7

Charfeddine, L. (2017). The Impact of Energy Consumption and Economic Development on Ecological Footprint and $\mathrm{CO}_{2}$ Emissions: Evidence from a Markov Switching Equilibrium Correction Model. Energy Economics, 65(1), 355-374. https://doi.org/10.1016/j.eneco.2017.05.009

Chen, Y., Wang, Z., \& Zhong, Z. (2019). CO2 Emissions, Economic Growth, Renewable and Non-Renewable Energy Production and Foreign Trade in China. Renewable Energy, 131(1), 208-216. https://doi.org/10.1016/j.renene.2018.07.047

Christopoulos, D. K., \& Leon-Ledesma, M. A. (2011). International Output Convergence, Breaks, and Asymmetric Adjustment. Studies in Nonlinear Dynamics \& Econometrics, 15(3), 1-35. https://doi.org/10.2202/1558-3708.1823

Danish, Zhang, B., Wang, B., \& Wang, Z. (2017). Role of Renewable Energy and NonRenewable Energy Consumption on EKC: Evidence from Pakistan. Journal of Cleaner Production, 156(1), 855-864. https://doi.org/10.1016/j.jclepro.2017.03.203

Destek, M. A., Ulucak, R., \& Dogan, E. (2018). Analyzing the Environmental Kuznets Curve for the EU Countries: The Role of Ecological Footprint. Environmental Science and Pollution Research, 25(29), 29387-29396. https://doi.org/10.1007/s11356-018-2911-4

Doğan, B., Saboori, B., \& Can, M. (2019). Does Economic Complexity Matter for Environmental Degradation? An Empirical Analysis for Different Stages of Development. Environmental Science and Pollution Research, 26(31), 31900-31912. https://doi.org/10.1007/s11356-019-06333-1

Dong, K., Sun, R., \& Dong, X. (2018). CO2 Emissions, Natural Gas and Renewables, 
Economic Growth: Assessing the Evidence from China. Science of the Total Environment, 640(1), 293-302. https://doi.org/10.1016/j.scitotenv.2018.05.322

Environmental Performance Index (2020). Available Online: https://epi.yale.edu/epi-results/2020/country/irn

Global Footprint Network (2010). Ecological Footprint Atlas 2010. Retrieved May, 25, 2014. https://www.footprintnetwork.org/

Global Footprint Network (2020). Available Online: http://data.footprintnetwork.org (Accessed on 4 July).

Grossman, G. M., \& Helpman, E. (1991). Quality Ladders in the Theory of Growth. The Review of Economic Studies, 58(1), 43-61. https://doi.org/10.2307/2298044

Grossman, G. M., \& Krueger, A. B. (1991). Environmental Impacts of a North American Free Trade Agreement. In: National Bureau of Economic Research (NBER) Working Papers Series, No. 3914.

Hacker, R. S., \& Hatemi-J, A. (2006). Tests for Causality between Integrated Variables Using Asymptotic and Bootstrap Distributions: Theory and Application. Applied Economics, 38(13), 1489-1500. https://doi.org/10.1080/00036840500405763

Hausmann, R., Hidalgo, C. A., Bustos, S., Coscia, M., \& Simoes, A. (2014). The Atlas of Economic Complexity: Mapping Paths to Prosperity: Mit Press.

Hidalgo, C. A., \& Hausmann, R. (2009). The Building Blocks of Economic Complexity. Proceedings of the National Academy of Sciences, 106(26), 10570-10575. https://doi.org/10.1073/pnas.0900943106

Horee, H. R., Galali, S. A., \& Gafare, S. (2013). Examining the Impact of Financial Development and Energy Consumption on the Environmental Degradation in Iran in the Framework of the Environmental Kuznets Curve Hypothesis (EKC). Iranian Energy Economics, 2(6), 27-48. http://jiee.atu.ac.ir/article_759.html

Hubacek, K., Guan, D., Barrett, J., \& Wiedmann, T. (2009). Environmental Implications of Urbanization and Lifestyle Change in China: Ecological and Water Footprints. Journal of Cleaner Production, 17(14), 1241-1248. https://doi.org/10.1016/j.jclepro.2009.03.011

Lee, K.-K., \& Vu, T. V. (2020). Economic Complexity, Human Capital and Income Inequality: A Cross-Country Analysis. The Japanese Economic Review, 71(4), 695-718. https://doi.org/10.1007/s42973-019-00026-7

Li, K., \& Lin, B. (2015). Impacts of Urbanization and Industrialization on Energy Consumption/ CO2 Emissions: Does the Level of Development Matter? Renewable and Sustainable Energy Reviews, 52(1), 1107-1122. https://doi.org/10.1016/j.rser.2015.07.185

Liu, H., Kim, H., Liang, S., \& Kwon, O.-S. (2018). Export Diversification and EcologicalFootprint:AComparativeStudy onEKCTheoryamong Korea,Japan, andChina. Sustainability, 10(10), 3657-3669. https://doi.org/10.3390/su10103657

Maddison, A. (2001). The World Economy: A Millennial Perspective: The Development Center of the Organization for Economic Cooperation and Development.

Madlener, R., \& Sunak, Y. (2011). Impacts of Urbanization on Urban Structures and Energy Demand: What Can We Learn for Urban Energy Planning and Urbanization Management? Sustainable Cities and Society, 1(1), 45-53. https://doi.org/10.1016/j.scs.2010.08.006

McNown, R., Sam, C. Y., \& Goh, S. K. (2018). Bootstrapping the Autoregressive Distributed Lag Test for Cointegration. Applied Economics, 50(13), 1509-1521. 
https://doi.org/10.1080/00036846.2017.1366643

Mobarak, A., \& Mohammadlou, N. (2010). The Impact of Trade Liberalization on Greenhouse Gases Emissions: an Empirical Test of Pollution Haven Hypotheses and Environmental Kuznets Curve. The Journal of Planning and Budgeting, 14(1), 31-58. http://jpbud.ir/article-1-175-fa.html

Molaei, M., \& Basharat, E. (2015). Investigating Relationship between Gross Domestic Product and Ecological Footprint as an Environmental Degradation Index. Journal of Economic Research (Tahghighat-E-Eghtesadi), 50(4), 1017-1033. https://dx.doi.org/10.22059/jte.2015.56156

Munir, Q., Lean, H. H., \& Smyth, R. (2020). CO2 Emissions, Energy Consumption and Economic Growth in the ASEAN-5 Countries: ACross-sectional Dependence Approach. Energy Economics, 85(1), 104571. https://doi.org/10.1016/j.eneco.2019.104571

Nahidi Amirkhiz, M., Rahimzadeh, F., \& Shokouhifard, S. (2020). Study of the Relation among Economic Growth, Energy Using and Greenhouse Gas Emissions (Case study: Selected Countries of the OIC). Journal of Environmental Science and Technology, 22(3), 13-26. http://jest.srbiau.ac.ir/article_12735.html

Narayan, P. K., \& Narayan, S. (2010). Carbon Dioxide Emissions and Economic Growth: Panel Data Evidence from Developing Countries. Energy Policy, 38(1), 661-666. https://doi.org/10.1016/j.enpol.2009.09.005

Neagu, O. (2019). The Link between Economic Complexity and Carbon Emissions in the European Union Countries: A Model Based on the Environmental Kuznets Curve (EKC) Approach. Sustainability, 11(17), 4753-4780. https://doi.org/10.3390/su11174753

Neagu, O., \& Teodoru, M. C. (2019). The Relationship between Economic Complexity, Energy Consumption Structure and Greenhouse Gas Emission: Heterogeneous Panel Evidence from the EU Countries. Sustainability, 11(2), 497-526. https://doi.org/10.3390/su11020497

OEC (2020). Economic Complexity Rankings. Available at: https://oec.world

Panayotou, T. (1993). Empirical Tests and Policy Analysis of Environmental Degradation at Different Stages of Economic Development. International Labour Office (ILO), Working Paper, WP238.

Pata, U. K. (2021). Renewable and Non-Renewable Energy Consumption, Economic Complexity, $\mathrm{CO} 2$ Emissions, and Ecological Footprint in the USA: Testing the EKC Hypothesis with a Structural Break. Environmental Science and Pollution Research, 28(1), 846-861. https://doi.org/10.1007/s11356-020-10446-3

Pesaran, M. H., Shin, Y., \& Smith, R. J. (2001). Bounds Testing Approaches to the Analysis of Level Relationships. Journal of Applied Econometrics, 16(3), 289-326. https://doi.org/10.1002/jae.616

Pritchett, L. (1997). Divergence, Big Time. Journal of Economic Perspectives, 11(3), 3-17. Ranis, G., \& Fei, J. C. (1961). A Theory of Economic Development. The American Economic Review, 51(4), 533-565.

Romer, P. M. (1990). Endogenous Technological Change. Journal of Political Economy, 98(5, Part 2), 71-102. https://doi.org/10.1086/261725

Saboori, B., \& Sulaiman, J. (2013). CO2 Emissions, Energy Consumption and Economic Growth in Association of Southeast Asian Nations (ASEAN) Countries: A Cointegration Approach. Energy, 55(1), 813-822. https://doi.org/10.1016/j.energy.2013.04.038 
Salmanpour, A., Mousavi, S. K., \& Shokouhifard, S. (2016). The Effect of Foreign Direct Investment on Gross Domestic Saving in Iran. Economic Development Policy, 4(4), 9-33. https://dx.doi.org/10.22051/edp.2018.17529.1121

Savci, S. (2012). An Agricultural Pollutant: Chemical Fertilizer. International Journal of Environmental Science and Development, 3(1), 77-80.

Shahzad, U., Fareed, Z., Shahzad, F., \& Shahzad, K. (2021). Investigating the Nexus between Economic Complexity, Energy Consumption and Ecological Footprint for the United States: New Insights from Quantile Methods. Journal of Cleaner Production, 279(1), 123806. https://doi.org/10.1016/j.jclepro.2020.123806

Sinclair-Desgagné, B. (2008). The Environmental Goods and Services Industry. International Review of Environmental and Resource Economics, 2(1), 69-99.

Smith, A. (1776). The Wealth of Nations: Princeton Review.

Stern, D. I. (2017). The Environmental Kuznets Curve after 25 Years. Journal of Bioeconomics, 19(1), 7-28. https://doi.org/10.1007/s10818-017-9243-1

Swart, J., \& Brinkmann, L. (2020). Economic Complexity and the Environment: Evidence from Brazil. Paper Presented at the Universities and Sustainable Communities: Meeting the Goals of the Agenda 2030. World Sustainability Series. https://doi.org/10.1007/978-3-030-30306-8_1

Tarazkar, M. H., Ghorbanian, E., \& Bakhshoodeh, M. (2017). The Effect of Economic Growth on Environmental Sustainability in Iran: Application of Ecological Footprint. Journal of Environmental and Natural Resource Economics, 2(3), 51-70. https://dx.doi.org/10.22054/eenr.2017.9067

Teimouri, I., Salarvandian, F., \& Ziarii, K. (2014). The Ecological Foot Print of Carbon Dioxide for Fossil Fuels in the Shiraz. Geographical Research, 29(1), 193-204. https://jgr.ui.ac.ir/article_18035.html

Torabi, T., Khajooeipour, A., Tarighi, S., \& Pakravan, M. (2015). The Effect of Energy Consumption, Economic Growth and International Business on Greenhouse Gas Emission in Iran. Economic Modeling, 9(29), 63-84. http://eco.iaufb.ac.ir/article_556765.html

Usman, O., Iorember, P. T., \& Olanipekun, I. O. (2019). Revisiting the Environmental Kuznets Curve (EKC) Hypothesis in India: The Effects of Energy Consumption and Democracy. Environmental Science and Pollution Research, 26(13), 13390-13400. https://doi.org/10.1007/s11356-019-04696-z

Wackernagel, M., \& Rees, W. (1998). Our Ecological Footprint: Reducing Human Impact on the Earth (Vol. 9): New society publishers.

Waheed, R., Sarwar, S., \& Wei, C. (2019). The Survey of Economic Growth, Energy Consumption and Carbon Emission. Energy Reports, 5(1), 1103-1115. https://doi.org/10.1016/j.egyr.2019.07.006

Wang, Z., Yang, L., Yin, J., \& Zhang, B. (2018). Assessment and Prediction of Environmental Sustainability in China Based on a Modified Ecological Footprint Model. Resources, Conservation and Recycling, 132(1), 301-313. https://doi.org/10.1016/j.resconrec.2017.05.003

Yilanci, V., \& Ozgur, O. (2019). Testing the Environmental Kuznets Curve for G7 Countries: Evidence from a Bootstrap Panel Causality Test in Rolling Windows. Environmental Science and Pollution Research, 26(24), 24795-24805. https://doi.org/10.1007/s11356-019-05745-3

Yilanci, V., \& Pata, U. K. (2020a). Convergence of Per Capita Ecological Footprint among the ASEAN-5 Countries: Evidence from a Non-Linear Panel Unit Root Test. Ecological 
Indicators, 113(1), 106178. https://doi.org/10.1016/j.ecolind.2020.106178

Yilanci, V., \& Pata, U. K. (2020b). Investigating the EKC Hypothesis for China: The Role of Economic Complexity on Ecological Footprint. Environmental Science and Pollution Research, 27(1), 32683-32694. https://doi.org/10.1007/s11356-020-09434-4

Yilanci, V., Bozoklu, S., \& Gorus, M. S. (2020). Are BRICS Countries Pollution Havens? Evidence from a Bootstrap ARDL Bounds Testing Approach with a Fourier Function. Sustainable Cities and Society, 55(1), 102035. https://doi.org/10.1016/j.scs.2020.102035

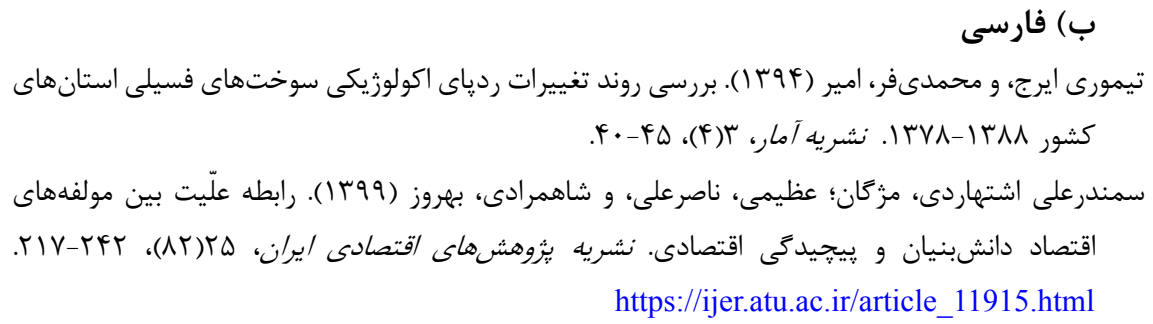

